\title{
Neolithisation of Sava-Drava-Danube interfluve at the end of the 6600-6000 BC period of Rapid Climate Change: a new solution to an old problem
}

\author{
Katarina Botić \\ Institute of Archaeology, Zagreb, CR \\ kbotic@iarh.hr
}

\begin{abstract}
The idea of the Neolithisation of the Sava-Drava-Danube interfluve has undergone very little change since $S$. Dimitrijevic's time. Despite their many shortcomings, new archaeological excavations and radiocarbon dates of Early Neolithic sites have provided us with new insight into the process of Neolihisation of this region. Using the recently published work by B. Weninger and L. Clare (Clare, Weninger 2010; Weninger et al. 2009; Weninger et al. 2014) as a starting point, the available radiocarbon and archaeological data are used to build up a time frame comparable to the wider region of Southeast Europe and climate conditions for specific period. The results fit the model of Neolithisation well (Weninger et al. 2014.9, Fig. 4), filling in the geographical gaps.
\end{abstract}

IZVLEČEK - Premise o neolitizaciji v medrečju Save, Drave in Donave se od časa S. Dimitrijevića niso veliko spremenile. Nova arheološka izkopavanja in radiokarbonski datumi zgodnjega neolitika so, kljub mnogim pomanjkljivostim, prinesli nove vpoglede v proces neolitizacije na tem območju. Za osnovo pri interpretaciji smo uporabili nedavno objavljena dela B. Weningerja in L. Clarea (Clare, Weninger 2010; Weninger et al. 2009; Weninger et al. 2014), dosegljive radiokarbonske datume in arheološke podatke pa smo uporabili za izdelavo časovnega okvirja, ki je primerljiv s širšim območjem jugovzhodne Evrope in s klimatskimi pogoji za posamezna obdobja. Rezultati dobro ustrezajo uveljavljenemu modelu neolitizacije (Weninger et al. 2014.9, Fig. 4) ter zapolnjujejo geografske vrzeli v modelu.

KEY WORDS - Neolithisation; Starčevo culture; northern Croatia; flooding episodes; Rapid Climate Change (RCC)

\section{Introduction}

The Early Neolithic of Sava-Drava-Danube interfluve, situated on the southern edge of the Carpathian basin, was marked by Starčevo culture. It first appeared in western Syrmia and eastern Slavonia, spreading through Baranja and western Slavonia and further west along the Drava River sometime around or slightly after $6000 \mathrm{BC}$. Over 100 Starčevo culture sites are known today, but only a handful have been excavated, and even fewer properly published. Data from four sites are used in this paper: Sopot, Zadubravlje - Dužine, Slavonski Brod Galovo and Virovitica - Brekinja (Fig. 1). The earli- est radiocarbon dates can be attributed to features exhibiting the full so-called Neolithic package. The south-east to north-west direction of spread of Neolithisation can be observed through the available radiocarbon dates.

The first relative chronology of Starčevo culture for the region in question was determined by Stojan Dimitrijević (1969.40; 1979.237-238). This chronology is still in use, and no attempts have been made to challenge it or to attribute absolute dating to its phases1.

1 Kornelija Minichreiter added to it Linear C phase for the western Drava region (1992.54-55), but she concentrated more on internal chronologies of specific sites than on the absolute dating of Starčevo culture phases in general. The only exception is the attempt to date the white painted Linear A phase at Galovo site (Minichreiter 2007b) but without reference to the full problem of Neolithisation. 
In recent years, new interdisciplinary studies appeared that enabled more complex analysis and offered different solutions to the problem of Neolithisation in the wider region from the Middle East, through south-east Europe and beyond. Whether they deal with possible climatic impact on Neolithisation from the climatological point of view (Perry, Hsu 2000; Migowski et al. 2006; Weninger et al. 2006; 2009; 2014; Kuper, Kröpelin 2006; Budja 2007; Clare et al. 2008; Gronenborn 2009; Berger, Guilaine 2009; Clare, Weninger 2010; Weninger, Clare 2011; Zielhofer et al. 2012; Reimer et al. 2013, etc.) or predominantly from the archaeologi-

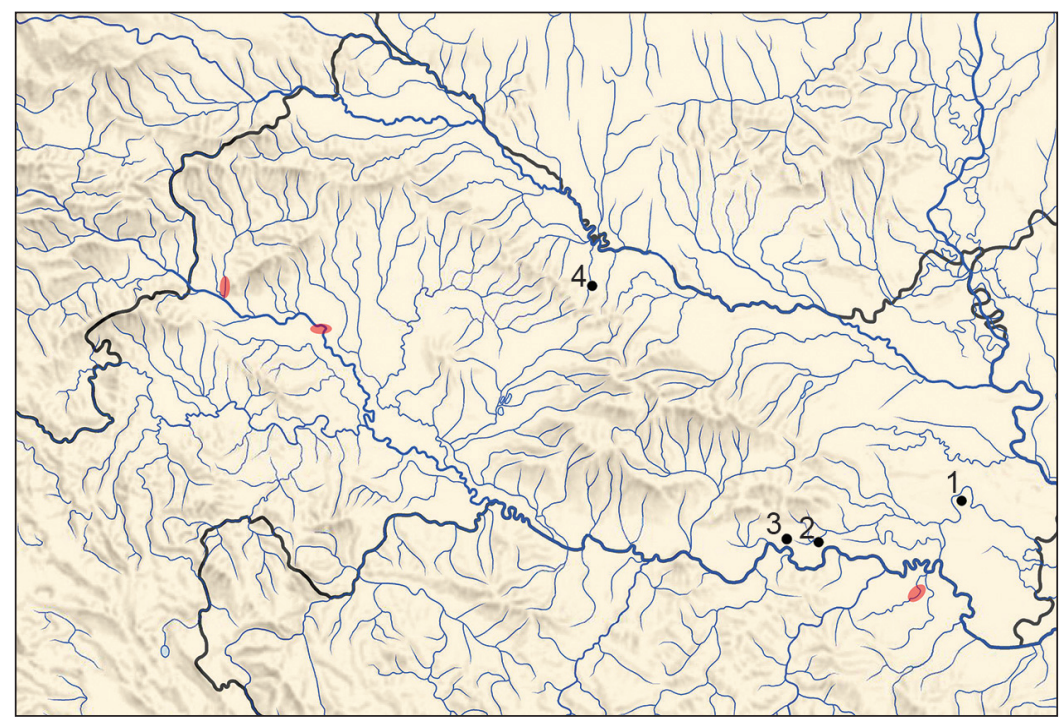

Fig. 1. Starčevo culture sites mentioned in the text: 1 Sopot; 2 Zadubravlje - Dužine; 3 Slavonski Brod - Galovo; 4 Virovitica - Brekinja. Sites of sub-fossil wood extraction mentioned in the text (from east to west): Oštra luka; Sava River near Rugvica; mouth of the Krapina River. cal point of view (Jurić et al. 2001; Bonsall et al. 2002; Bonsall 2007; Bánffy et al. 2007; Borić, Dimitrijević 2007a; Bánffy, Sümegy 2012; Bánffy 2013a; Salisbury et al. 2013; Lespez et al. 2013; Gurova, Bonsall 2014; Krauß et al. 2014; Botić 2016, etc.), they offer answers to some very old questions on this subject.

\section{Relative chronology of Starčevo culture in north- ern Croatia}

The basic typological periodisation and relative chronology of Starčevo culture in northern Croatia was determined by Dimitrijević (1969.40; 1979.237-238) with very few later additions (Minichreiter 1992. 54-55; Marković 1994.62-63). Dimitrijević separated Starčevo culture into seven phases: Monochrome, Linear A, Linear B, Girlandoid, Spiraloid A, Spiraloid $\mathrm{B}$ and the Final Ždralovi phase (1969.40; 1979.237238). Kornelija Minichreiter later added Linear C phase (Minichreiter 1992.54-55), which she considers parallel to Spiraloid A phase in eastern Slavonia and Baranja. Zorko Marković's proposed chronological system was never accepted (Marković 1994. 62-63) ${ }^{2}$. No recent attempts have been made to further study the problem of the relative chronology of Starčevo culture, except Minichreiter's internal chronologies of the Zadubravlje - Dužine, Slavonski Brod - Galovo, and Pepelana sites (Minichrieter 1992; $2007 a ; 2007 b ; 2007 c$ ), although the problem of chronological sequences of these phases and their apparent parallel appearance in different regions still waits to be addressed.

\section{An old problem}

The process of Neolithisation of the Sava-Drava-Danube interfluve has not been properly addressed since Dimitrijević's time. The development of early Neolithic Starčevo culture was observed by Minichreiter mostly in the light of new excavations carried out at the Pepelana, Zadubravlje and Galovo sites in terms of internal chronology (Krajcar Bronic, Minichreiter 2007; 2011; Minichreiter 2001; 2007a; 2007b; 2007c; 2010; Minichreiter, Botić 2010; Minichreiter, Krajcar Bronic 2006) but the process itself was not the focus of Minichreiter's research.

Dimitrijević presumed the existence of an initial Monochrome phase (Dimitrijevic 1969) even describing pottery finds (Dimitrijevic 1969.40; Minichreiter 1992.7-8), but sites containing finds from this presumed phase were never documented in northern Croatia (Minichreiter 1992.41, 54; 2007b.23), not even after the large-scale rescue excavations on highways, bypasses etc. carried out in the last 15 years. Dimitrijevićs second presumed Linear phase (Dimitrijevic 1969), more specifically Linear A (Dimitrijević 1979.237; Minichreiter 2007b.22-23),

2 Phases are: Starčevo 1, Starčevo 2-A, Starčevo 2-B, Starčevo 3, Starčevo 4-A and Starčevo 4-B. His phases are parallel to Dimitrijević's. 
was confirmed at the Slavonski Brod - Galovo site (Minichreter 2007a.16; 2007b) where white painted pottery was found, and at the Zadubravlje site, which had no white painted pottery, although the coarse pottery shows characteristics of this phase (Minichreiter 1992.35; 2007c.173): the lack of channelled barbotine decoration and lack of biconical vessel forms. Dark painted Linear B phase (Dimitrijevic 1979.237) was attested at both the Zadubravlje and Galovo sites, the latter exhibiting white and dark painted linear pottery in all three features mentioned by Minichreiter (Minichreiter 2007b) ${ }^{3}$. However, according to Dimitrijević (1979.242-246), barbotine and channelled barbotine decoration was introduced in the Linear B phase, which is absent from both of these sites, although some fragments with amorphous relief appliqués appear (Minichreiter 1992.35, 69, 101, Tab. 19.1; 2007a.93).

The last campaign at the Sopot site also provided some fragments of white painted pottery, although some fragments were found earlier scattered over the site out of context ${ }^{4}$. How and where the so-called Neolithic package reached northern Croatia and how that affected the Mesolithic way of life remain unanswered question.

There is another problem concerning most of the new and some of the old archaeological excavations: most of the finds were never published. The same holds for the radiocarbon dates obtained from these excavations. They have not been published or are published without any actual context, or perhaps with just a short description of the feature they were collected from. Thus, the view of how and where the neolithisation started in this region is limited. Nevertheless, data available, although limited, can provide a basis for a new interpretation of the beginning of Neolithic in northern Croatia.

\section{${ }^{14} \mathrm{C}$ sequences of four sites}

From over hundred Starčevo culture sites only six have been radiocarbon dated 5 and only four of these sites have usable data ${ }^{6}$. From Sopot near Vin- kovci (Fig. 1.1), Zadubravlje - Dužine (Fig. 1.2), Slavonski Brod - Galovo (Fig. 1.3). and Virovitica - Brekinja sites (Fig. 14) 37 radiocarbon dates are available, most of them from Galovo (Tab. 1) ${ }^{7}$. Reconstructing a time frame from a limited number of radiocarbon dates per site, the obvious difference in quantity from site to site, the limited information about the context from which the samples were taken, etc., is methodologically questionable, but it is the only information available at the moment.

\section{Sopot near Vinkovci (Fig. 1.1)}

The Sopot site was systematically excavated from 1996 until 2008 in 13 campaigns (Krznarić Škrivanko 2015.372) although there were several previous excavations during the 20 th century (Krznarić Škrivanko 2015.371-372). The excavations focused on a late Neolithic Sopot culture tell settlement, but during the last campaign in 2008: "Dug into the pre-sterile layer (prehistoric humus), for the first time at Sopot, a structure was excavated which can be attributed to the Starčevo culture. Pit dwelling SU 519 was dated to the period between 6060 and 5890 BC." (Krznarić Škrivanko 2015.378) (Fig. 2) ${ }^{8}$. The pit was found on the easternmost side of the excavated area, very close to the summit of the settlement plateau (Krznaric Škrivanko 2009.90). The pottery from this pit was coarse, but according to the excavator, fragments of white painted pottery were discovered before, scattered over the site out of context 9 . These finds have not been published yet. The area excavated was $375 \mathrm{~m}^{2}$, several metres in depth (Krznaric Škrivanko 2011.212; 2015.375).

Three dates are available, from pit SU 519 (Beta 251910) and two pre-virgin soil layers SU 80 (Beta 251909) and 143 (Beta 251911) (Fig. 3; Tab. 1). All three dates group around $6000 \mathrm{BC}$ or just slightly earlier. These are the oldest dates for Starčevo culture in northern Croatia so far. The existence of two layers into which the Starčevo feature was dug in may suggest one or more episodes of flooding sealing off the Starčevo layer, rather than being layers

3 Pits 9, 205, and 207 .

4 See note 9 .

5 Only the published data were taken into consideration, with the exception of one unpublished date from Galovo provided by Dr Kornelija Minichreiter, for which we are grateful.

6 Dates from Tomašanci - Palača site were published as a 5660-5300 BC range without details (Balen, Gerometta 2011.84, note 2) and for Belišce - Staro Valpovo site the date was published as 6400-5450 BC, a sample being taken from a male skeleton, but with no other information (Šimić 2007a.34, note 4; 2007b.10; 2012.27). Both sites were excluded from this paper.

7 Sopot 3 dates; Zadubravlje 8 dates; Brekinja 2 dates; Galovo 24 dates.

8 Krznarić Škrivanko (2011.219) mentions two layers (80 and 143) through which this structure was dug in. These two layers were detected over other areas at the site and contained sporadic Starčevo finds (Krznarić Škrivanko 2009.90).

9 M. Krznarić Škrivanko, personal communication. 
of prehistoric humus. The next occupation level at this site appears almost 1000 years later during the late Neolithic Sopot culture 10 .

Zadubravlje - Dužine site (Fig. 1.2) Rescue excavations on the site were carried out in 1989 and 1990. An area of $6200 \mathrm{~m}^{2}$ was excavated (Minichreiter 1992.31; 1993.93; 2001.203, Fig. 4). Several large and small pits were explored, comprising working and living areas, many post holes, several kilns and a well (Minichreiter 1992; 1993a; 2001). No white painted pottery was reported from this excavation, but dark
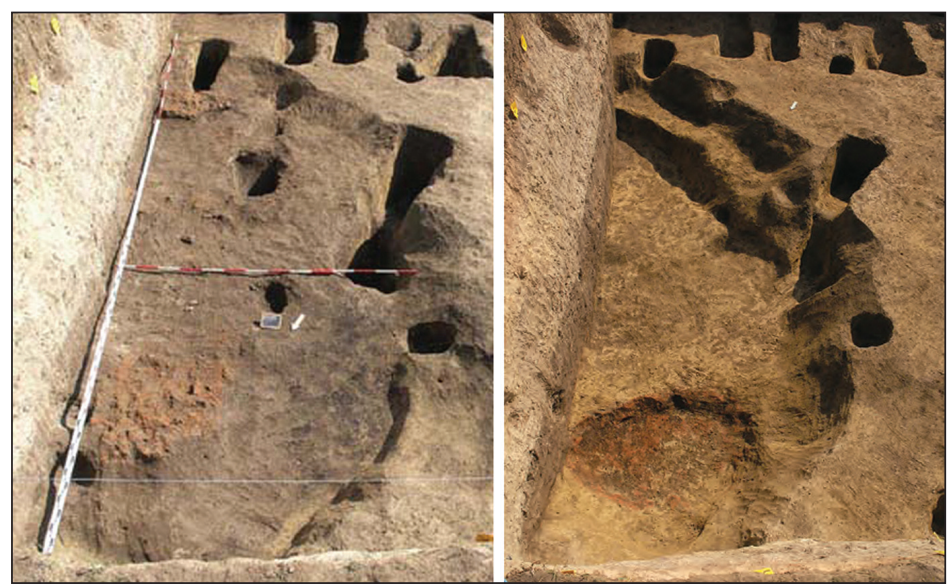

Fig. 2. Pit-dwelling 519 during and after the excavation (after Krznarić Škrivanko 2009.91; 2015.378, Fig. 11). painted linear motifs were found together with coarse pottery characteristic of Linear A phase ( $\mathrm{Mi}$ nichreiter 1992.35, 103, Tab. 21; 2007c.173).

Eight radiocarbon dates are available from this site (Fig. 4; Tab. 1). The oldest date (Z-2924) comes from a sample taken from the well. It was probably taken from a larger beam or a trunk and may be considered old wood; it was not taken into further consideration in this paper. Most of the dates group between 5900 and 5600 BC (Fig. 4; Tab. 1) with one exception (Z-2925).

\section{Slavonski Brod - Galovo site (Fig. 1.3)}

The site is situated about $9 \mathrm{~km}$ west of the Zadubravlje - Dužine site. The excavations started in 1997 and are continuing. An area of around $3000 \mathrm{~m}^{2}$ yielded 11 large pits which are considered burial pits, pitdwellings and working pits, one above ground struc- ture (Minichreiter 2010; Minichreiter, Botić 2010. 107), several large fences, a large number of post holes and smaller pits 11 . White painted pottery was found in pits 9, 205, and 207 (Fig. 5) although most of the painted pottery in all three pits exhibit dark motifs (Minichreiter 2007b). Here, as at Zadubravlje site, the coarse pottery corresponds to Dimitrijević's definition of Linear A phase (Dimitrijević 1979. 243).

At the end of its life, the site was covered with an $80 \mathrm{~cm}$ layer of sediment indicating no later occupation except a late Bronze Age necropolis (Minichreiter 2007a.33-34).

Twenty-four dates are available from this site, but some should be excluded. Some samples may have been contaminated by water from flooding episodes ${ }^{12}$, while others (Z-3586, Z-3584) may be consi-

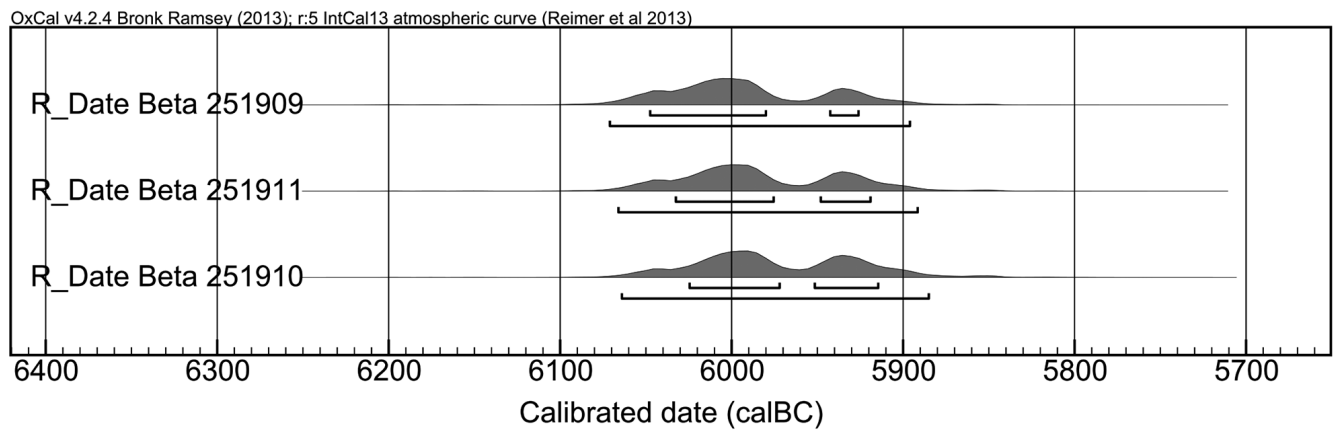

Fig. 3. Sopot ${ }^{14} \mathrm{C}$ dates.

10 The oldest house SU 23 is dated to $6020 \pm 100 \mathrm{BP} / 5050-4780 \mathrm{BC}(68.2 \%)(\mathrm{Z}-3139)$ and $6010 \pm 100 \mathrm{BP} / 5040-4770 \mathrm{BC}(66.35 \%)$ (Z-3140) (Krznarić Škrivanko 2011.211, Tab. 1).

11 The last section excavated since 2010 was only published in short reports (Minichreiter 2011; 2012; 2013; 2014; 2015).

12 Most probably samples Z-5043, Z-5044, Z-4879 and Z-4880. The site was damaged by clay exctraction for a brick factory now closed, and there is a large hole to its north-east side. After heavy rains, water sometimes reaches the level of the site. Damage could have been done to unexcavated features with $80 \mathrm{~cm}$ of sediment already removed from their top. However, the oldest date from pit 323 (Z-4357) comes from the nearby southern area of the site, which could not have been affected by flood episodes. Further detailed analysis of the material from the southern pits is required. 


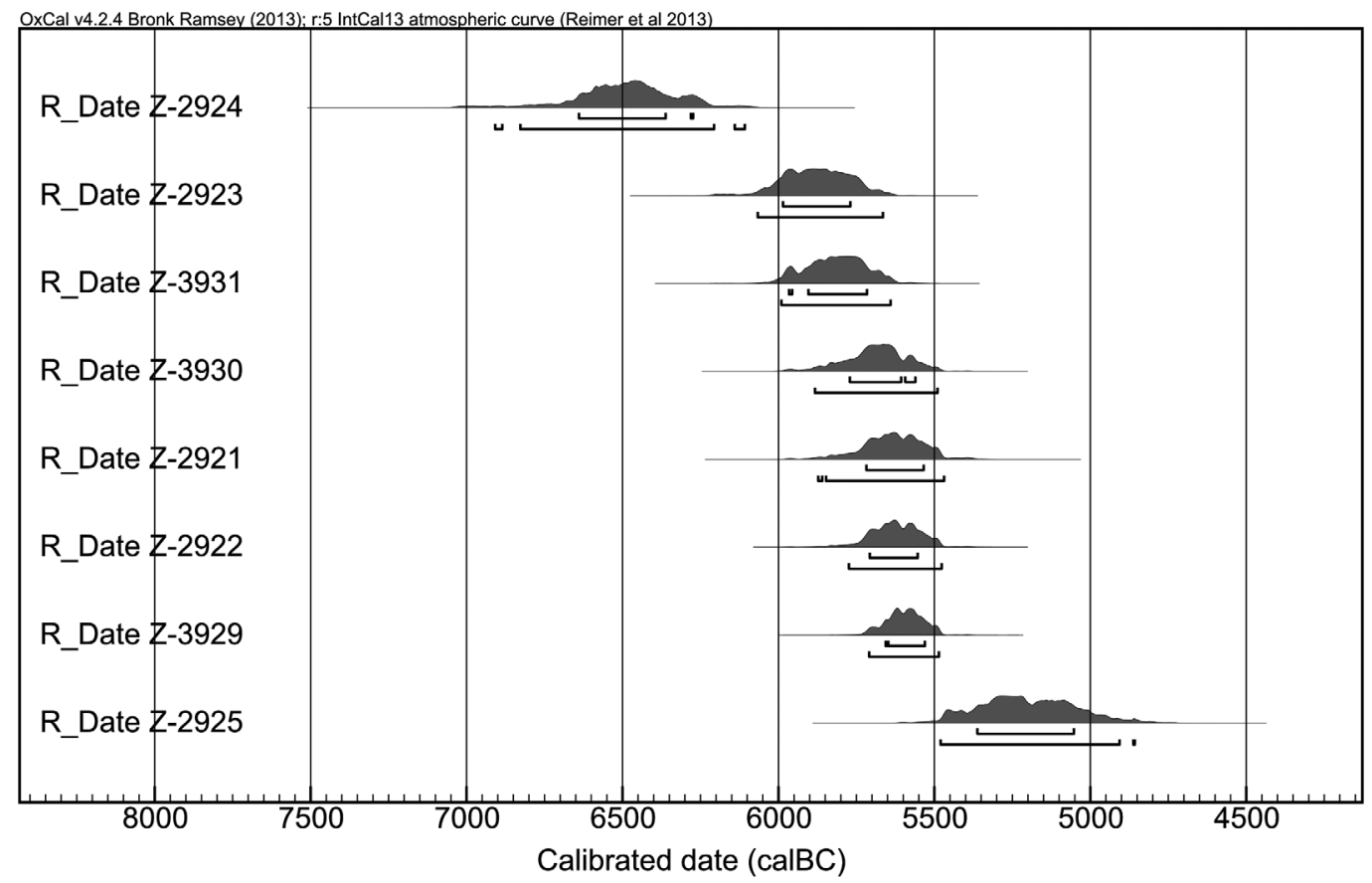

Fig. 4. Zadubravlje - Dužine ${ }^{14} \mathrm{C}$ dates.

dered old wood. Most of the dates group between 5800 and $5550 \mathrm{BC}$ although a younger group of dates can be observed between 5500 and probably 5150 BC (Fig. 6). This group of dates belongs to the part of the feature (Z-3925, the youngest hearth from a pit 9 containing burials) or features (Z-3583, pit-dwelling 37; Z-2935 pit 15 containing male burial) situated on the north side of the site. However, if we consider the possible validity of the three oldest dates (Z-4357, Z-3586, Z-3584), then a third phase of the settlement can be added which would represent slightly younger phase than at the Sopot site and an almost parallel phase at Zadubravlje site.

\section{Virovitica - Brekinja site (Fig. 1.4)}

The site was excavated in 2005 on the future western Virovitica by-pass road. An area of $9000 \mathrm{~m}^{2}$ was explored, but Starčevo culture features were found only on $5400 \mathrm{~m}^{2}$. Merely the border area of the settlement was excavated, yielding a few partially explored features interpreted as working and residential areas. Most of the finds were fragments of coarse pottery with a barbotine surface. No painted pottery was found. The excavators date this site to the Spiraloid B phase (Sekelj-Ivančan, Balen 2007).

Only two dates are available from this site (Fig. 7), but unfortunately no description of the context from which the samples were taken has been published. The dates confirm the late existence of this site, probably between 5500 and $5300 \mathrm{BC}$.
Time span of Starčevo culture in northern Croatia (Fig. 8)

Although scarce information about Starčevo culture sites is available, it is nevertheless possible to reach some preliminary conclusions about its time span:

(1) Sopot: So far, there are no traces of settlement at this site before $6060 \mathrm{BC}$ (Beta 251909, Beta 251911, Beta 251910). After 5880 BC, early Neolithic life ends and life is renewed only a thousand years later.

(2) Zadubravlje - Dužine: The oldest date 6850-6100 $\mathrm{BC}$ from a wooden beam in the well (Z-2924) should not be taken into consideration as the oldest date for this settlement, but the date 60675666 BC (Z-2923) could indicate this first phase. The youngest date (Z-2925) corresponds to dates from the Virovitica - Brekinja site.

3 Slavonski Brod - Galovo: The oldest date is from a small pit 323 from the south side of the excavated area (Z-4357) while the next two dates (Z$3586, \mathrm{Z}-3584$ ) are from the two wooden fences. These three samples group just after $6000 \mathrm{BC}$. The next group of dates is the largest, and groups between 5800 and $5550 \mathrm{BC}$. The three youngest dates (Z-3925, Z-3583, Z-2935) range from about 5500 to $5100 \mathrm{BC}$; these samples were taken from pits 9, 15 and 37 situated on the northern side of the site. 
(4) Virovitica - Brekinja: Two dates from this site belong to the period between 5500 and $5300 \mathrm{BC}^{13}$.

It is worth noting that three of the sites, Sopot, Galovo, and Zadubravlje ${ }^{14}$, were at some point covered by one or several layers of sediment. These layers sealed off the sites for a considerable time: at Sopot, for about a thousand years, and at Galovo until the
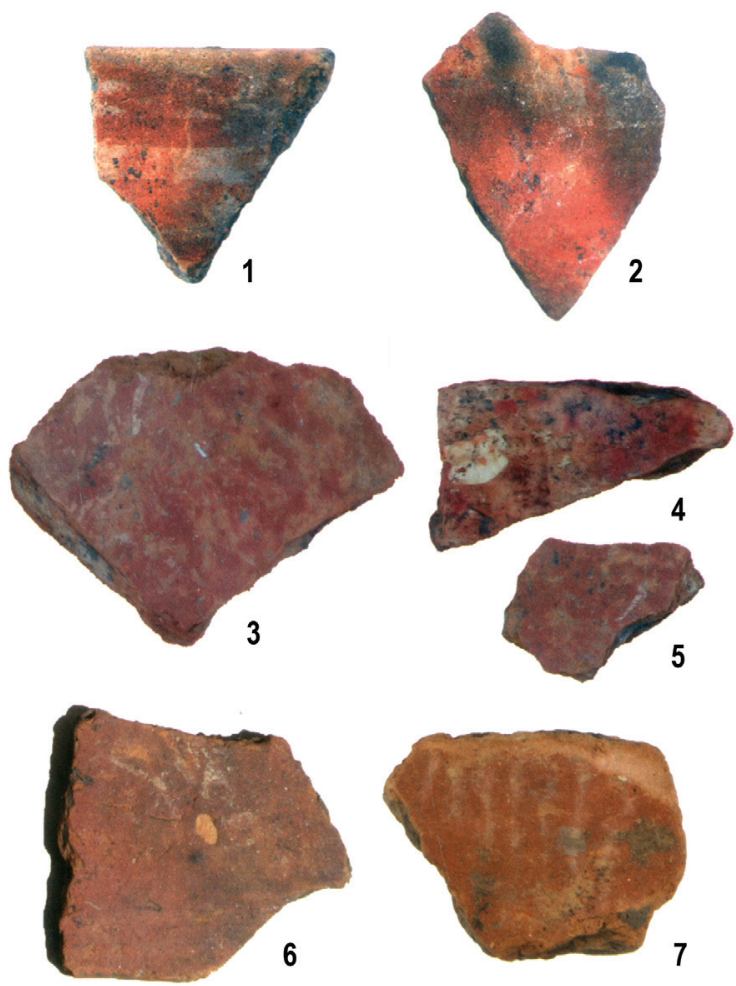

Fig. 5. Slavonski Brod - Galovo, white painted pottery. 1-2 working pit 205; 3-5 working pit 207; 6-7 pit 9 with 3 burials (modified after Minichreiter 2007b.31, Fig. 4). end of the Bronze Age. Life at Zadubravlje site was never renewed.

The sum of all the usable dates from all four sites (Fig. 8) shows the existence of Starčevo culture in this area roughly between $6000 \mathrm{BC}$ (or slightly earlier) and $5300 \mathrm{BC}$. Obvious problems with some dates make it impossible to firmly establish the boundaries of phases, but it is possible to establish a time frame for further discussion in this paper.

The overview of ${ }^{14} \mathrm{C}$ dates provided by Bernhard Weninger et alii (2014) from central Anatolia to north-east Hungary (Fig. 9) can be complemented with the dates available for north Croatia, filling in the geographical gap. It is also clear that Neolithisation reached northern Croatia just after 6600-6000 $\mathrm{BC}$, following after the Bulgarian and Romanian dates ${ }^{15}$, but before the Hungarian dates (Hertelen$d i$ et al. 1995.242, Tab. 1). On the territory of Serbia the oldest dates come from southern Serbia ${ }^{16}$, while the Iron Gates 17 and Donja Branjevina site (Budja 2009.127, Tab. 1, 129, Tab. 2; 2013.42. Fig. 1) ${ }^{18}$ show very similar dates to those from northern Croatia.

\section{New solution - RCC 6600-6000 as terminus post quem}

For a new interpretation of the beginning of the Neolithic in northern Croatia, it is necessary to have a closer look at investigations of the Holocene climate fluctuations of the northern hemisphere. Recent palaeoclimate research has discovered the existence of a distinctly repetitive series of cooling ano-

13 During the preparation of this paper, new ${ }^{14} \mathrm{C}$ dates were obtained for the Našice - Velimirovac, Arenda 1 site (situated northwest of Našice, near Velimirovac). A rescue excavation was carried out in 2011 on the Našice by-pass road. The dates obtained

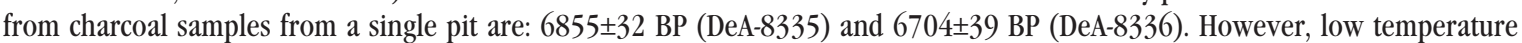
combustion yielded $6822 \pm 23 \mathrm{BP}$ and $6804 \pm 25 \mathrm{BP}$, showing better results. These are the oldest dates for the Drava region, predating most of the dates at Zadubravlje, half of the dates from Galovo (both in Sava region) and dates from Virovitica - Brekinja site situated further west. The pottery shows traces of black painted motifs on a red surface, the most similar to the Girlandoid phase according to Dimitrijević (1969.36-37). Similar finds were collected at the Našice - Brick factory site (Minichreiter $1992.16 ; 86, T .4$ ) about $4 \mathrm{~km}$ to the southeast. This is further confirmation of the somewhat later spread of Starčevo culture to the Dravina region. It is still an open question if flooding prevented the advance of the Neolithic to the west along Drava River. $14 \mathrm{~K}$. Minichreiter, personal communication.

15 Similarity of the earliest radiocarbon dates across the Balkans from southern Bulgaria (Dzhuljanitsa, Kovačevo) to Transilvania (Gurova, Bonsall 2014.100; Krauß et al. 2014). See also absolute chronology data for the Starčevo-Criș cultural complex (Luca et al. 2011; Biagi et al. 2005.44.Fig. 4; Biagi, Spataro 2005.38.Fig. 8a-b; 2008.342-343. Tab. 2).

16 Blagotin by 6200 BC (Whittle et al. 2002.107, 113; Bonsall 2007.55).

17 Vlasac was occupied before and after the 8.2 ka event (Boric et al. 2008.279.Fig. 22), but at Lepenski Vir there is a gap between 7200 and $6300 \mathrm{BC}$; the range of dates for the phase with trapezoidal buildings is $6240-5845 \mathrm{BC}$, while the early Neolithic context has range of dates 6005-5798 BC (Borić, Dimitrijević 2007a.67, 69).

18 Dates clearly group before and after $6000 \mathrm{BC}$, forming a boundary connecting Grivac, Lepenski Vir, Padina before $6000 \mathrm{BC}$ and the disappearance of this boundary after the $6000 \mathrm{BC}$, indicating two directions of spread of the Neolithic along important rivers: one through Divostin and along the Danube, north-west to Donja Branjevina, and the other to the north-east, along the Tisza and its tributaries to Pannonian Plain and Gura Baciului (Draşovean 2007.69). 


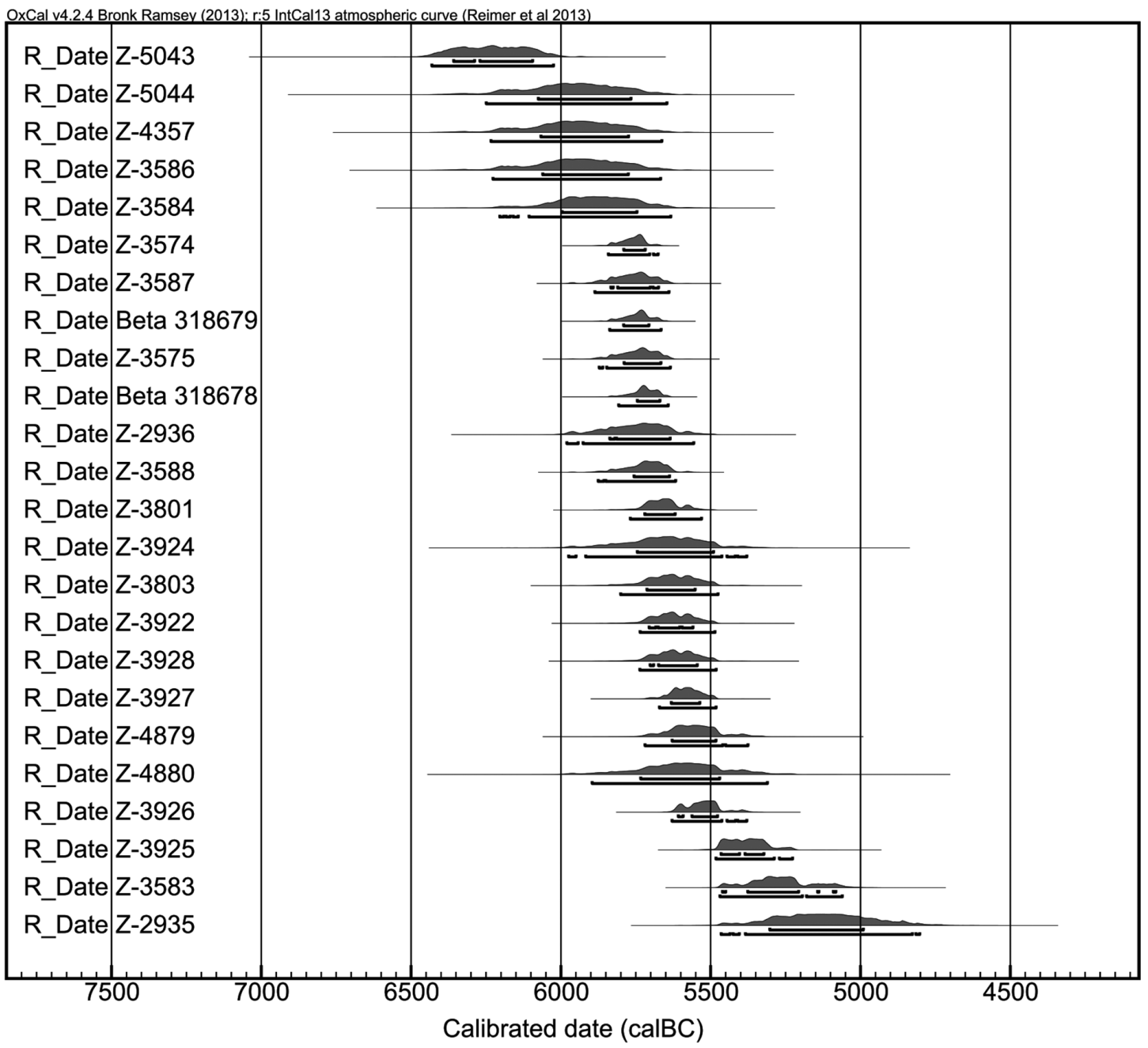

Fig. 6. Slavonski Brod - Galovo ${ }^{14} \mathrm{C}$ dates.

malies during the Holocene (Weninger et al. 2009; Weninger, Clare 2011.11) termed 'Rapid Climate Change' (RCC) events (Rohling et al. 2002; Mayewski et al. 1997; 2004; Clare et al. 2008; Weninger, Clare 2011.11; Budja 2015). The RCC intervals are: 9000-8000, 6000-5000, 4200-3800, 3500-2500, 1200-1000 and 600-150 BP, the most recent corresponding to the LIA (Mayewski et al. 2004; Budja 2007; Weninger et al. 2009; 2011; Clare, Weninger 2010). The main cause of these events, in addition to solar intensity weakening (Perry, Hsu 2000; Bond et al. 2001; Mayewski et al. 2004.244; Marino et al. 2009.3246), appears to have been a strengthening of atmospheric pressure gradients between Siberian (High), Iceland (Low) and the Azores (High), conditions supporting an influx of extremely cold air from the polar regions into Europe (Clare et al. 2008; Weninger et al. 2009; Clare, Weninger 2010; Weninger, Clare 2011; Weninger et al. 2014; Weninger, Harper 2015.478, Fig. 2; Benito et al. 2015.5). RCC events correlate with ice-rafted debris (IRD) events (Bond et al. 1997) although not entirely. Further- more, the North Atlantic Oscillation (NAO) positive phases may have been connected to these cold events (Bout-Roumazeilles et al. 2007.3212).

The most severe of these events was the $8.2 \mathrm{ka}$ event (6600-6000 BC) (Alley et al. 1997; Magny et al. 2003; Alley, Ágústsdóttir 2005; Thomas et al. 2007; Clare et al. 2008; Gronenborn 2009; Marino et al. 2009; Weninger et al. 2009; Weninger et al. 2014) during which temperatures in the North Atlantic region dropped over the course of the subsequent 160 years (Thomas et al. 2007.75; Weninger et al. 2009. 11). This cooling event was amplified between 8.2 and $8.0 \mathrm{ka}$ calBP by the collapse of a remnant Laurentide ice-dome and subsequent drainage of large amounts of melt-water from the Hudson Bay into the North Atlantic (Bauer et al. 2004; Budja 2007. 191; Marino et al. 2009.3246; Weninger et al. 2009. 11-12; 2014.8; Weninger, Clare 2011.17) resulting in one of the most extreme climate anomalies of the entire Holocene (Weninger et al. 2014.10). Marine Core LC21 from the southeast Aegean to the east 


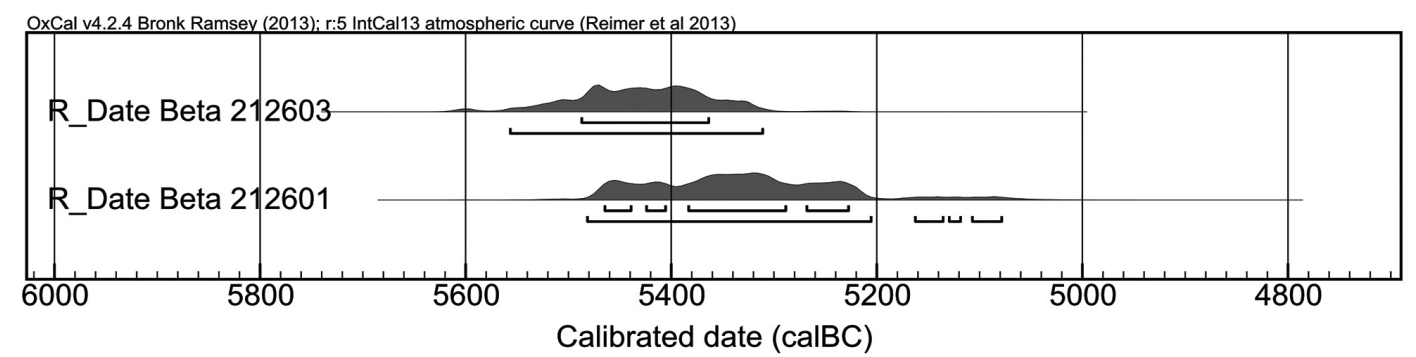

Fig. 7. Virovitica - Brekinja ${ }^{14} \mathrm{C}$ dates.

of Crete showed rapid sea-surface temperature variations resulting from the rapid movement of extremely cold air masses over the surface of the Aegean Sea over a distance of some $700 \mathrm{~km}$ over short periods of time during winter and early spring (Weninger et al. 2009.10; 2014.10; Weninger, Harper 2015). Cold and dry air flowing rapidly over a warm ocean surface caused evaporation (Weninger et al. 2009.11), which in turn could have provoked intensive precipitation (Weninger et al. 2009.33). Similar cooling events were documented for the Adriatic Sea (Siani et al. 2013; Budja 2015.172). However, in Eastern Mediterranean periods of extreme drought were documented, such as the low levels of Dead Sea (Migowski et al. 2006; Budja 2007.194; Weninger et al. 2009.15-16) (Fig. 10.H), during which 'flash-flood' events would have had devastating results on the environment and human occupation (Weninger et al. 2009.33). Weninger et alii (2014. 14) distinguish two phases: an earlier phase at $6600-$ $6200 \mathrm{cal} \mathrm{BC}$ (RCC only) and a later phase at 62006000 cal BC (RCC amplified by Hudson Bay impact).

Northern Africa was arid until $8500 \mathrm{BC}$, when an abrupt arrival of monsoon rains created savannahlike environmental conditions, which prompted the swift population of the area by $7000 \mathrm{BC}$; conditions changed back to arid after $5300 \mathrm{BC}$ (Kuper, Kröpelin 2006.806.Fig 3). Nile River sediments record an enhanced riverine contribution between 8600 and 5500 calBP, indicating enhanced precipitation in north-east Africa (Magny, Combourieu Nebout 2013. 1449). The aridity in North Africa, southern Near East and Middle East is due to the reduced northward migration of the Intertropical Convergence Zone (ITCZ) in summer (Berger, Guilaine 2009.41). Southern Europe shows similar records, indicating that it should be integrated into the same climatic zone during the 8200 calBP event (Berger, Guilaine 2009.41).

In Europe during the $8.2 \mathrm{ka}$ event, low latitudes were affected by colder and more arid conditions, especially in winter (Alley et al. 1997; Alley, Ágústs- dóttir 2005; Berger, Guilaine 2009.35.Fig. 3). German oak tree-ring records show a distinct low (Fig. 11) (Alley, Ágústsdóttir 2005.1127; Budja 2007.192; Berger, Guilaine 2009.37; Weninger et al. 2014.15. Fig. 9), implying poor growing spring and summer conditions (Alley, Ágústsdóttir 2005.1127; Budja 2007.193; Berger, Guilaine 2009.37; Cufar et al. 2014.1275).

In southern-central Europe, pollen spectra show a sudden disappearance of Corylus avellana (hazel) and rapid expansion of Pinus (pine), Betula (birch) and Tilia (lime) and an invasion of Fagus sylvatica (beech) and Abies alba (fir). This change in vegetation is thought to relate to annual temperature decreasing by about $2-3^{\circ} \mathrm{C}$ and increased moisture availability. The rapid retreat of drought-adapted Corylus was probably caused by taller and longerlived trees (Pinus, Betula, Tilia, Quercus, Ulmus, Frayinus excelsior, etc.) (Tinner, Lotter 2001; 2006; Budja 2007.194; Nafradi et al. 2015. 14, Dörfler 2013.322). Research conducted at Prokoško jezero in central Bosnia, the closest to our region of interest, showed similar trends: from $7360 \mathrm{BC}$ until 5500 BC a distinct change occurred, when Fagus increased rapidly and became the dominant species in subalpine woodlands, closely followed by Abies, while Corylus greatly decreased; Betula, Quercus and Tilia values diminish, while Carpinus orientalis (oriental hornbeam) and Picea slightly increase (Dörfler 2013.325). The difference in vegetation is noted for north-western Greece (Rezina marshes - Willis 1992, and Boras Mountains - Lawson et al. 2005): the spread of thermofilic trees starts with Quercus, Abies and Carpinus orientalis, followed after some 1000 years by Corylus and Ulmus, and after another 1000 years by Tilia (Dörfler 2013.329). Fagus and Abies values are very low in the Rezina marshes (Dörfler 2013.329). In north-west Romania (Preluca Tiganului and Steregoiu) pollen-based analysis showed a drop of $1.5-2^{\circ} \mathrm{C}$ in mean annual temperature, $2-4^{\circ} \mathrm{C}$ in mean temperature of the coldest month, and an increase in mean temperature of the warmest month, while precipitation shows a de- 


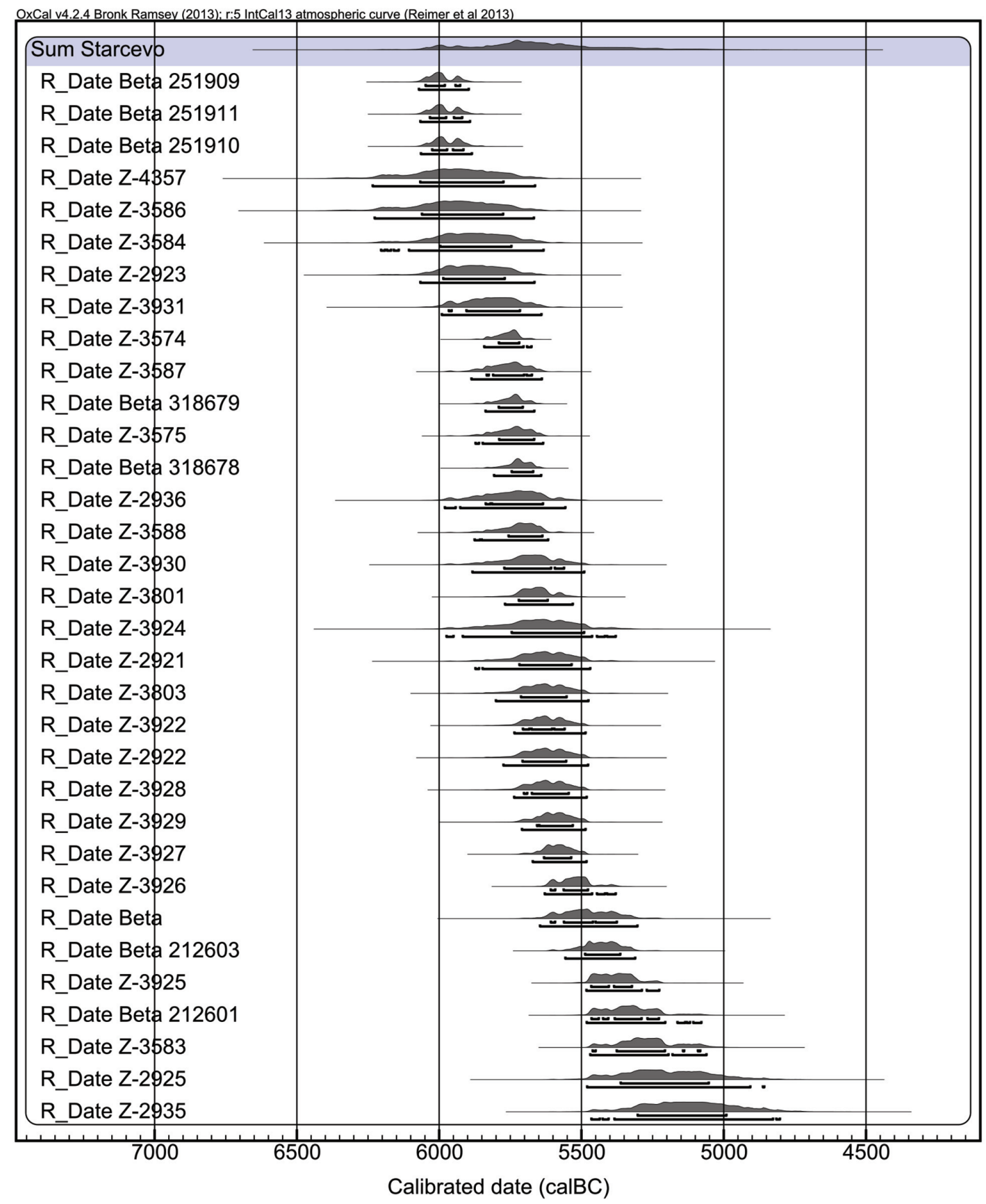

Fig. 8. Sum of ${ }^{14} \mathrm{C}$ dates for Starčevo culture in northern Croatia.

crease of about $200 \mathrm{~mm}$. This suggests an intensification of seasonality and continentality (Feurdean et al. 2008.500).

European mid-latitudes between $43^{\circ}$ and $50^{\circ} \mathrm{N}$ underwent wetter conditions in response to cooling, while northern and southern latitudes were marked by drier climate (Magny et al. 2003.1593; Alley, Ágústsdóttir 2005.1128; Budja 2007.194; Berger, Guilaine 2009.37, 40.Fig. 6). Increasing cyclonic activity over mid-latitudes consecutive to a southward displacement of the Atlantic Westerly Jet and a strong thermal gradient between high and low lati- tudes could have been the cause of hydrological tripartition of Europe (Magny et al. 2003.1592.Fig. 2, 1593-1594.Fig. 3; Budja 2007.194-195.Fig. 3; Berger, Guilaine 2009.41). Lake sediment and palaeobotanical records from Alpine region indicate cooler and wetter conditions between 8500 and $7800 \mathrm{cal}$ BP (Haas et al. 1998; Bonsall et al. 2002.2; Magny et al. 2003.1592; Berger, Guilaine 2009. 37; Budja 2015.172 ) while wet winters and wet summers are documented in southern regions below $40^{\circ} \mathrm{N}$ (Budja 205.172) marked by sea surface salinity lowering and reduced deep-sea convection during the sapropel S1 phase between 9.3 and $7.4 \mathrm{ka}$ (Magny, Com- 


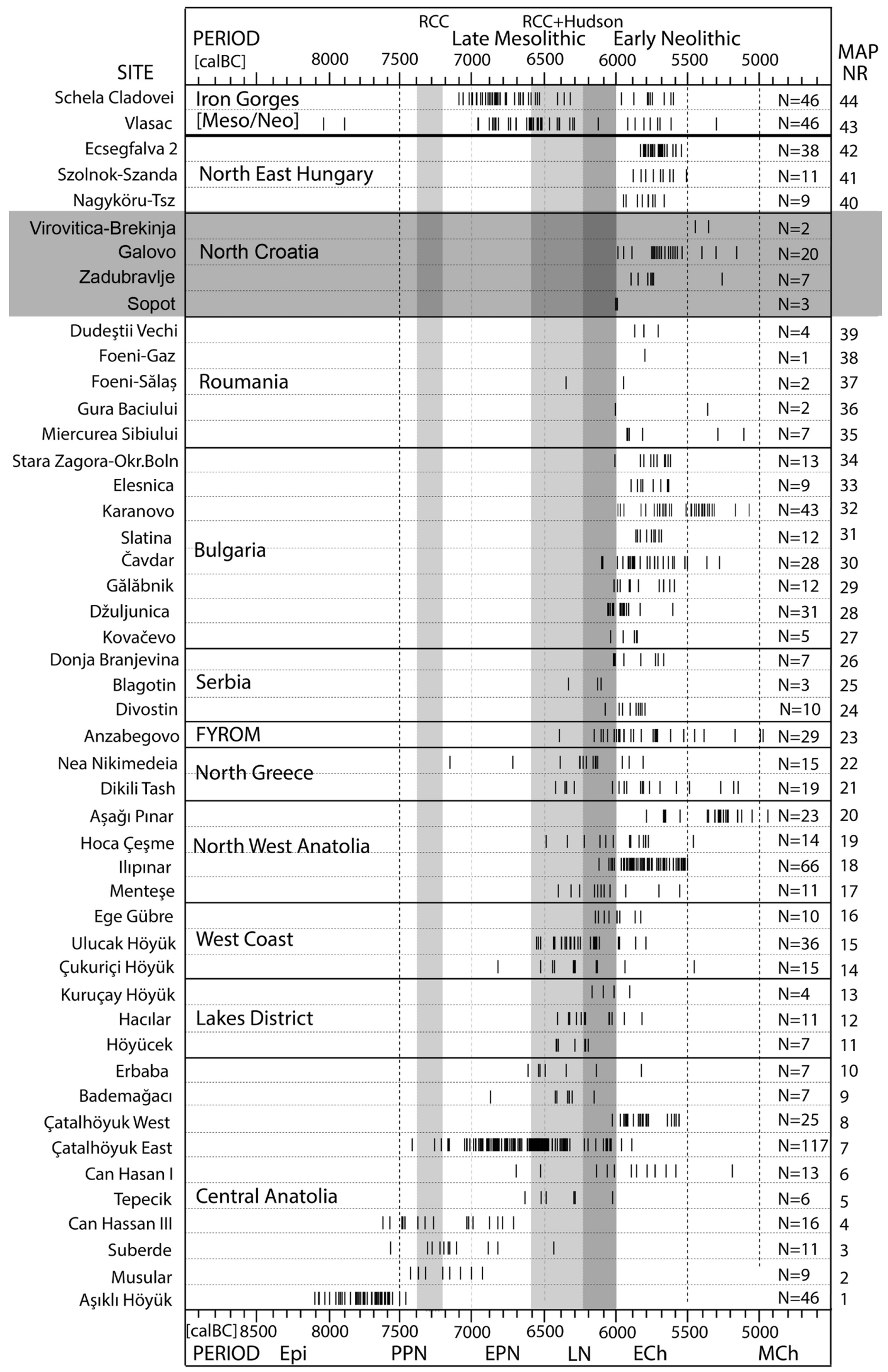

Fig. 9. Overview of ${ }^{14}$ C-ages (modified after Weininger et al. 2014.9.Fig. 4). 


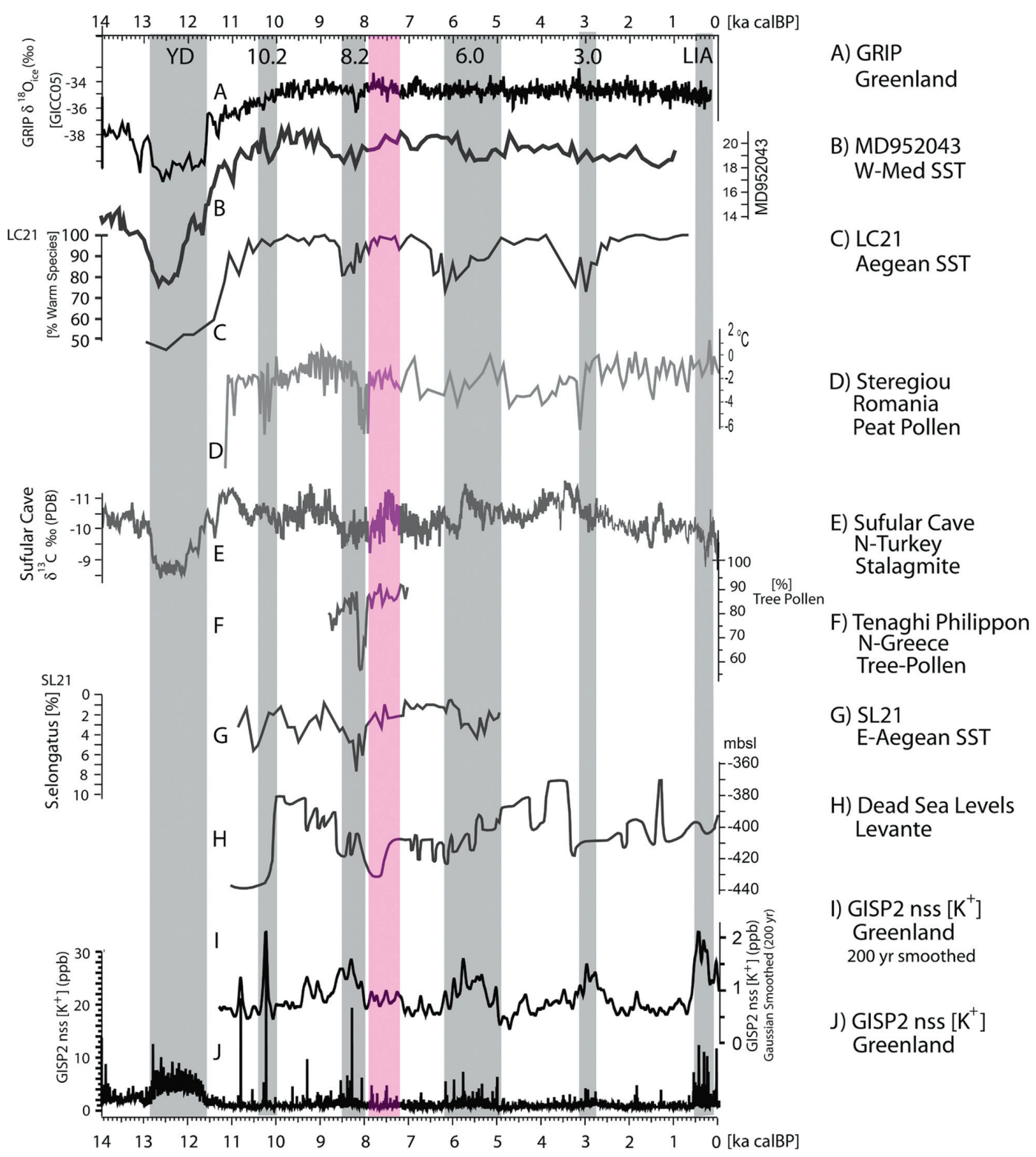

Fig. 10. Northern Hemisphere Palaeoclimate Records showing Holocene Rapid Climate Change (RCC). The purple line marks the duration of the early Neolithic in northern Croatia (modified after Weininger et al. 2014.11.Fig. 5).

bourieu Nebout 2013.1449; Siani et al. 2013.510). There is also evidence for a major period of flooding in several parts of Europe, i.e. central Europe (fluvial episode associated with a massive accumulation of tree trunks in the Rhine Valley between 8500 and 8000 cal BP - Berger, Guilaine 2009.37-38), Britain, the Danube delta and specifically the French Alps between 8250 and 7950 BP (Bonsall et al. 2002.4). A recent study by Gerardo Benito et alii (2015) combines more than $2000{ }^{14} \mathrm{C}$ and OSL dated flood units from 12 regions in Europe and North Africa (Benito et al. 2015.2, Fig. 1), but unfortunately this study does not include data from regions between the Alps and the Black Sea including the entire Carpathian basin 19. Studies have shown that intensive runoffs of the Po, coastal Italian, Apennine and Albanian rivers may have had an impact on lowering salinity during the middle part of the Holocene in the south Adriatic Sea (Magny, Combourieu Nebout 2013.1449; Siani et al. 2013.505).

$19 \mathrm{It}$ is, however, interesting to note an increase in flooding after the $8.2 \mathrm{ka}$ event, first in temperate European regions and slightly after in Mediterranean regions (Benito et al. 2015.4, Fig. 3). These flood episodes in both regions correspond to IRD 5b, i.e. to the period between 5700 and $5100 \mathrm{cal} \mathrm{BC} \mathrm{(Gronenborn} \mathrm{2009.100;} \mathrm{Benito} \mathrm{et} \mathrm{al.} \mathrm{2015.4.Fig.} \mathrm{3),} \mathrm{adding} \mathrm{to} \mathrm{our} \mathrm{understanding} \mathrm{of}$ climatological conditions during the early Neolithic in northern Croatia and especially during its end. 


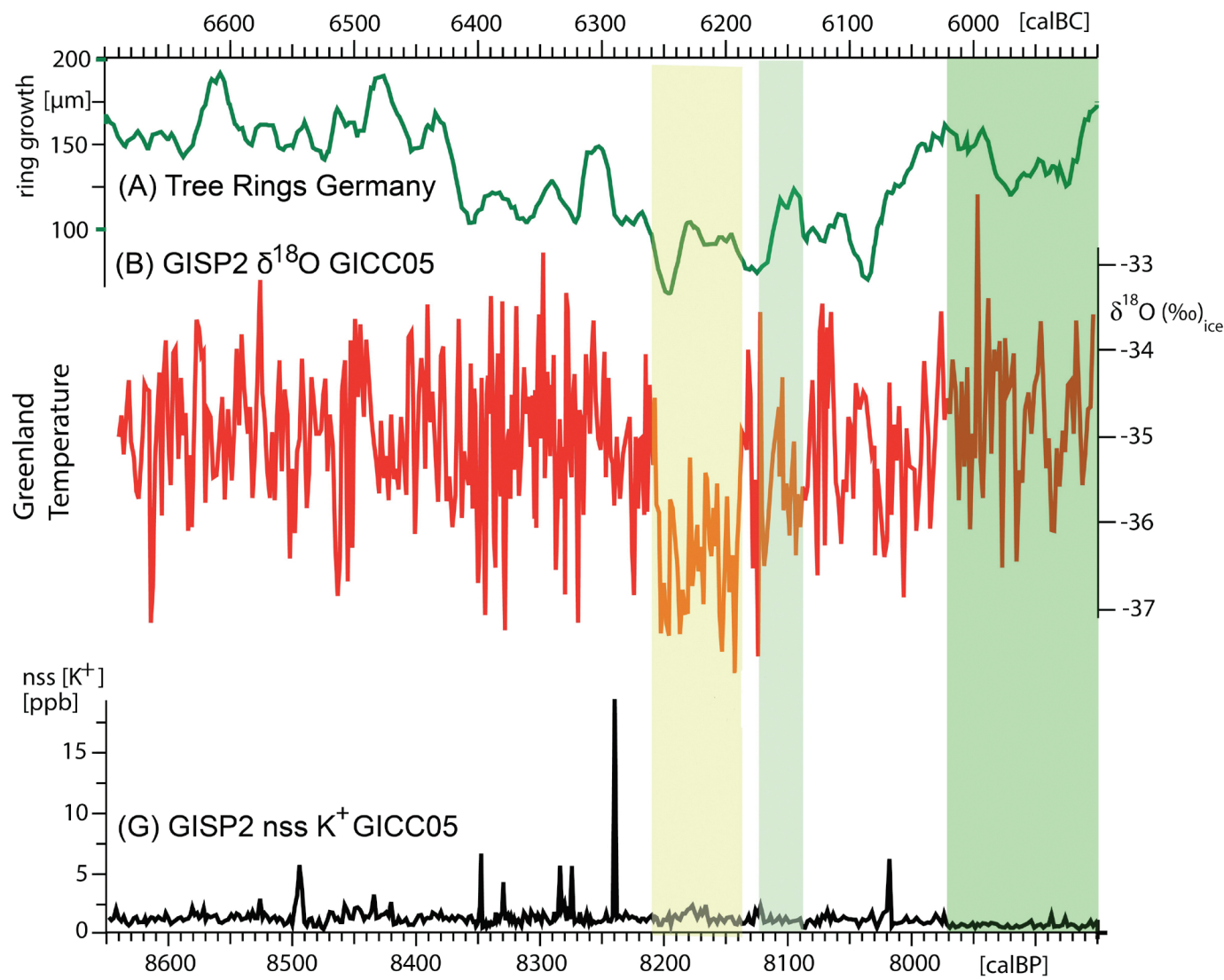

Fig. 11. Timing and structure of the $8.2 \mathrm{ka}$ calBP event on a global scale. The relevant time frame for the beginning and duration of early Neolithic in northern Croatia is marked in darker green (modified after Weininger et al. 2014.15.Fig. 9).

The end date for the $8.2 \mathrm{ka}$ event (Weninger et al. 2014 ) falls at $6000 \mathrm{BC}$, or slightly before. The available radiocarbon dates from the early Neolithic period from the Sava-Drava-Danube interfluves fall within the same time range. Thus, the end of the RCC 6600-6000 BC can be taken as a terminus post quem for the appearance of the early Neolithic in this region. It is important to stress that the full 'Neolithic package' is present at all the above-mentioned sites 20 .

\section{Discussion}

Several studies published in the last 15 years or so (Perry, Hsu 2000; Migowski et al. 2006; Weninger et al. 2006; 2009; 2014; Kuper, Kröpelin 2006; Budja 2007; Clare et al. 2008; Gronenborn 2009; Berger, Guilaine 2009; Clare, Weninger 2010; Weninger, Clare 2011; Zielhofer et al. 2012; Reimer et al. $2013, e t c$.) were dedicated to the observation of the
8.2 ka event impact on Neolithisation processes with some regard to archaeological evidence from the Middle East across the Eastern Mediterranean, northern Africa, and southern and central Europe. Others (Jurić et al. 2001; Bonsall et al. 2002; Bonsall 2007; Bánffy et al. 2007; Borić, Dimitrijević 2007a; Bánffy, Sümegy 2012; Bánffy 2013a; Salisbury et al. 2013; Lespez et al. 2013; Gurova, Bonsall 2014; Krauß et al. 2014; Botic 2016, etc.) take the archaeological context more into consideration but recognise the possible climatic influence on Neolithisation process from the Middle East to central Europe or at least deal with ecological/environmental conditions that could have enabled or prevented the spread of Neolithisation at specific point in time. These studies seem to indicate a halt in Neolithisation advances caused by the $8.2 \mathrm{ka}$ event, which led to unfavourable conditions across certain European regions, mainly the Carpathian basin and other regions of temperate Europe.

20 At the Sopot site, only a partial pit was excavated, but it contained coarse pottery and an altar (Krznarić Škrivanko 2015.Fig. 12). White painted fragments were collected at similar depths across the site, but out of context and radiocarbon dates come from teeth (Krznaric Škrivanko 2011.223, Tab. 3), although it is not clear if the teeth are from animals and if they are from domesticated species. 
Eszter Bánffy and Pál Sümegi (2012) discuss the role of the Central European-Balcanic Agro-Ecological Barrier (CEBAEB) 21 in the Carpathian Basin as a zone of interaction between immigrant farming communities and the local forager population, although the reasons for the existence of the barrier were manifold: the climatic conditions on the southern side of the boundary were favourable, but the soil was sandy and unsuitable for long-term settlement and crop cultivation (Bánffy, Sümegi 2012.59), especially given the limited agricultural knowledge of immigrant communities adapted to different conditions in south-eastern Europe; the specific climatic conditions in Carpathian Basin due to the basin effect (Bánffy, Sümegi 2012.59) which could trigger a unique transformation in vegetation and soil types; wet habitats and sandy ridges more suitable for a Mesolitic population based on hunting and foraging (Bánffy, Sümegi 2012.60) etc. The German oak tree-ring record22 (Fig. 11) shows another low between 6000 and $5900 \mathrm{BC}$, possibly indicating unfavourable climate conditions such as excess of precipitation that could have caused large-scale and unpredictable floods (Bonsall et al. 2002; Bonsall 2007) representing impenetrable barriers, although their intensity could have been less pronounced than in the previous $8.2 \mathrm{ka}$ period. However, some of the barriers recognised, such as the one in the Kalocsa area and Tolna Sárköz region (the southern Danube region in Hungary), are difficult to explain using ecological/environmental arguments (Bánffy $2013 b$ ). Borić (2011) does not see the gap in the settlement of the area between the late Mezolithic and early Neolithic in the Iron Gates gorge; gaps can be seen at certain sites, while others were settled during that time. Borić also does not agree with Bonsall (Bonsal et al. 2002; Bonsall 2007) that largescale floods were the reason for discontinuity of occupation of sites, but considers different economic strategies to be the reason for that. It is also clear in the Iron Gates gorge that Early/Middle Neolithic
(5950/5900-5500 BC) settlements are at least to a point situated in different environments and on different soils (such as Aria Babi) (Borić 2011.183).

The question is whether some kind of ecological barrier existed in the Sava-Drava-Danube interfluve, influencing the emergence and spread of Neolithisation in this region or whether this spread was dictated by some other reasons, such as in the Tolna Sárköz region. So far, specific environmental analysis compared with archaeological data has not been done for the Sava-Drava-Danube region, and only circumstantial data are available which might give an insight into the climatic conditions of this region during the Neolithic. In a recently published paper (Pearson et al. 2014) two sub-fossil wood samples are of interest for the region discussed here. Samples 25 from Oštra Luka near Orašje and 151 from the mouth of Krapina River near Zagreb yielded very interesting dates (Fig. 12-13). The date for sample 25 from Oštra Luka is almost identical to three dates from Sopot (Fig. 3) and the date for sample 151 from the Krapina River coincides with the beginning of flood episodes (Benito et al. 2015.4, Fig. 3c), which in turn coincide with IRD 5b (Bond et al. 2001.2131, Fig. 2; Gronenborn 2009.99, Fig. 2; Benito et al. 2015.4, Fig. 3b). As the extreme flooding in spring 2014 showed, extremely high precipitation in the central Bosnian mountain region can provoke extreme episodes of flooding of the Vrbas, Bosna and lower flow of the Sava rivers. This scenario may have happened around $6000 \mathrm{BC}$ or slightly after; debris could have sealed off the Sopot site for the next 1000 years 23,24 .

Interestingly, in the Prokoško jezero pollen record, a significant drop in the Corylus record and a rapid increase of Fagus are noted around 6000 BC (Dörfler 2013.322, Fig. 11). This episode could have been provoked by increased precipitation.

21 CEBAB: an ecological-palaeoecological-mathematical model based on the combination of archaeological and the palaeoenvironmental evidence (Bánffy, Sümegi 2012.57-58).

22 The positive correlation between tree-ring widths and amount of summer precipitation in different months, the ambiguous effect

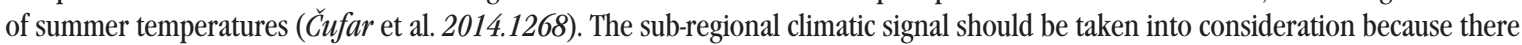
is clear evidence that the eastern part of the Sava-Drava-Danube interfluve shows a different climatic signal from the western part (Čufar et al. 2014.1272.Fig. 3).

23 The date for sample 151 from Krapina river may indicate climatic conitions just before the appearance of the Našice - Velimirovac, Arenda 1 site in Drava region (see note 13). The Krapina and Drava rivers respond to increased precipitation in pre-Alpine region, while the lower flow of Sava river responds to precipitation in the central Balkan region. Quite often, floods of the Krapina, Drava, Kupa and upper flow of the Sava rivers do not correspond to floods in the lower flow of Sava river because of this dual source of excess precipitation.

24 As mentioned above, this is all circumstantial evidence; nevertheless, the closeness of dates is striking. Bearing in mind that Starčevo culture was more extensive and more intensive presence in western Hungary can only be documented from around 57005550 cal BC (Bánffy 2013a.17), this circumstantial evidence carries even more weight. In this respect, the temporal map of the spread of Neolithisation from the Middle East to Europe (Gronenborn 2014) needs to be modified. 
The early Neolithic in Sava-Drava-Danube interfluve shows all the characteristics of full Neolithic package. White painted motifs on some fragments from the Galovo and Sopot sites suggest the earliest Linear A phase, although these fragments are accompanied by fragments with black painted motifs. The percentage of both white and black painted pottery is very low in the overall amount of pottery from all sites. There is a difference of opinion as to whether a Monochrome phase of early Neolithic existed throughout south-east Europe preceding the 'developed' Neolithic (Stojanovski et al. 2014.24): Lolita Nikolova (2007.91) puts Hoca Çeşme 4-3, Krajnitsi 1, Divostin 1, Koprivets 1, Dzhulyunitsa, and Smurdesh 1 sites in this phase, dating it to ?6300-6200/6100 cal $\mathrm{BC}$, while Krauß (2011) argues that the amount of painted pottery during the whole early Neolithic in south-eastern Europe is notably below 10\%, and that painted pottery was present from the very beginning in this region 25 . This latter can be applied to Sava-Drava-Danube region: the amount of painted pottery is well below $10 \%$ at observed sites and it is already present in the earliest dated sites. So far, no traces of Starčevo Monochrome phase have been found in our observed region (Minichreiter 1992.54; 2007b.23). Nevertheless, some sites in the Balkans were attributed to that earliest Monochrome phase: Krajnici, Koprivec and Poljanica-platoto in Bulgaria; Divostin, Donja Branjevina and Grivac in Serbia; Pešterica, Rudnik and Grnčarica in the Republic of Macedonia (Krauß 2010.41; Stojanovski et al. 2014), Foeni-Sălas and Gura Baciului in Romania (Drassovean 2007.70, Fig.2-4; Luca, Suciu 2007.79; Krauß 2010.36).

The question of the transition from late Mesolithic to early Neolihic is also open for discussion for SavaDrava-Danube region, because no Mezolihic sites are yet known from eastern Slavonia, which may be the result of later floods covering earlier sites or the state of current research. In the surrounding areas, the best-preserved and explored sites exhibiting the transition from Mesolithic to Neolithic are situated in the area of the Iron Gates (Krauß 2014.194). There, among other periods, the Late Mesolithic (c. 7400$6200 \mathrm{cal} \mathrm{BC}$ ) and Transformation period/Early Neolithic (c. 6200/6300-6000/5950 cal BC) can be distinguished (Boric 2011.161). There are several welldocumented Mesolithic sites in this region: Hajdučka
Vodenica, Icoana, Kula, Ostrovul Banului, Ostrovul Corbului, Ostrovul Mare, Padina, Schela Cladovei, Velesnica, and Vlasac (Borić 2011.163, Tab. 2; Borić et al. 2014). In the Transformation/Early Neolithic period only Hajdučka vodenica, Padina and Vlasac show uninterrupted occupation, while new sites appear: Ajmana, Alibeg, Lepenski Vir 26 and Stubica (Borić, Dimitrijević 2007a.69, Tab. 2; Borić et al. 2008.279; Borić 2011.163, Tab. 2; Borić et al. $2014)^{27}$. In the following Early/Middle Neolithic ( $c$. 5900-5500 BC) occupation continues in Ajmana, Hajdučka Vodenica, Icoana, Lepenski Vir, Padina, Schela Cladovei, Velesnica, and Vlasac and new sites appear: Ari Babi, Cuina Turcului, Donje Butroke, and Lepenski Abri (Borić 2011.163, Tab. 2).

In southern Banat, a part of the Iron Gates region, only two sites are known: Hoț Cave, near Steierdorf (Anina) and Băile Herculane-Hoților Cave (Krauß 2014.195). These sites are situated a few kilometres north of the Iron Gates in the hilly parts of the southern Carpathians, while in the northern part of the Banat, the Mesolithic is as yet unknown (Krauß 2014.195-196). In Bačka, Mesolithic sites are documented at Hajdukovo close to Subotica and at Bačka Palanka, west of Novi Sad; the sites are located exclusively on the banks of the alluvial plains of the rivers (Krauß 2014.196). In Transdanubia, the Regöly 2 site was recently explored, but there are some older finds from the vicinity of Gyôr, from the Sárrét bog, Csór-Merítópuszra, next to the village of Nádasdladány and from a sand dune on the flood plain of the Kapos River at Kapshomok (Krauß 2014.196). In Alföld, excavations were carried out at two sites in the Sződliged/Vác area, together with intensive survey in the Jászság area. The sites at Szôdliged are situated close to the Danube and are compared to Iron Gates sites by the excavators (Krauß 2014.201). Extensive surveys were carried out in Jászág Basin, the large flood plain between the upper Tisza and Danube rivers, and two Mesolithic sites were found: Jászberény I and Jásztelek I (Krauß 2014.201-202). Five more sites from the Alföld have been mentioned in the literature, some of them situated on the sandy dunes of the floodplains or close to major rivers (Krauß 2014.212). In the Sathmar district of north-west Romania Ciumesti II site is also situated on a dune (Krauß 2014.212).

25 In Dzhulyunitsa, the oldest layer contains black painted pottery, while only the second layer presents white painted pottery (Krauß et al. 2014; Dzhanfezova et al. 2014). It is also clear from a preliminary archaeometric study (Dzhanfezova et al. 2014) that all the pottery was locally made and that the presumed south-eastern imports do not exist.

26 For the non-existent Late Mesolithic period at Lepenski Vir (see Borić, Dimitrijević 2007b.51, Tab. 2; 2007b.69, Tab. 2; Borić 2011.169).

27 Note the change in view of the Mesolithic-Neolithic transition at Vlasac in papers by Borić et al. $(2008.279 ; 2014)$. 


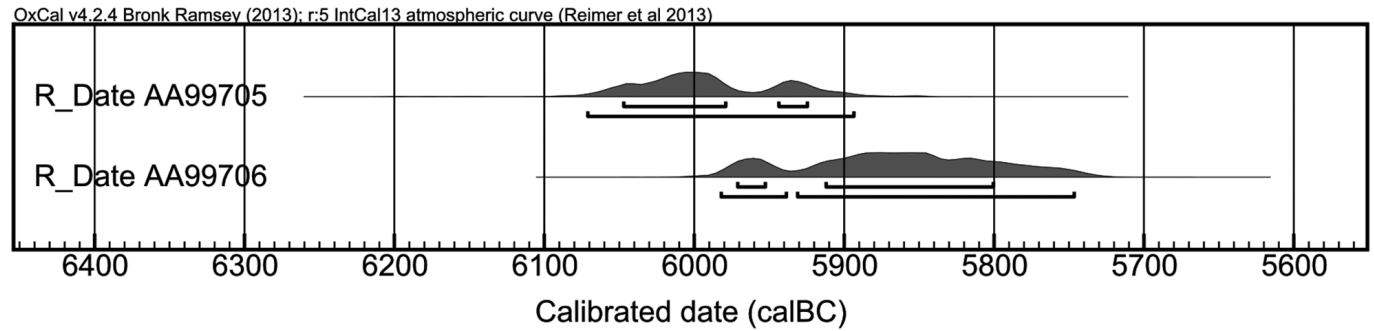

Fig. 12. ${ }^{14} \mathrm{C}$ dates for two sub fossil samples: AA99705 = sample 25 and AA99706 = sample 151 (after Pearson et al. 2014.S54, Tab. 2).

Maria Gurova and Clive Bonsall (2014), comparing known data for Upper Palaeolithic and Late Mesolithic sites in the Balkans, show the peripheral distribution of latter sites within the Balkans. In their assessment, most of the sites are located within $50 \mathrm{~km}$ of the sea or the Danube. One of the reasons for Mesolithc peripheral site distribution could have been the change in vegetation cover - from semi-desert steppe and forest-steppe ecosystems to a major expansion of temperate forest during the early Holocene. Dense forests protected animals, thus reducing hunting productivity and they have also "posed significant challenges for inter-group communication and participation in viable mating networks" (Gurova, Bonsall 2014.98). Edible plants in temperate forest ecosystems are found on the forest margins, such as upland tree lines, recently burned areas or along sea, lake and river shores. Aquatic resources became an essential substitute for the lack of animal biomass (Gurova, Bonsall 2014.97-98).

Bearing in mind the specific site positions on dunes near large rivers or at elevations near floodplains, the change in resources due to the change in the environment and appearance of dense temperate forests, it is clear that the lack of Mesolithic sites in the Sava-Drava-Danube region, specifically eastern Slavonia, was partially due to environmental change at

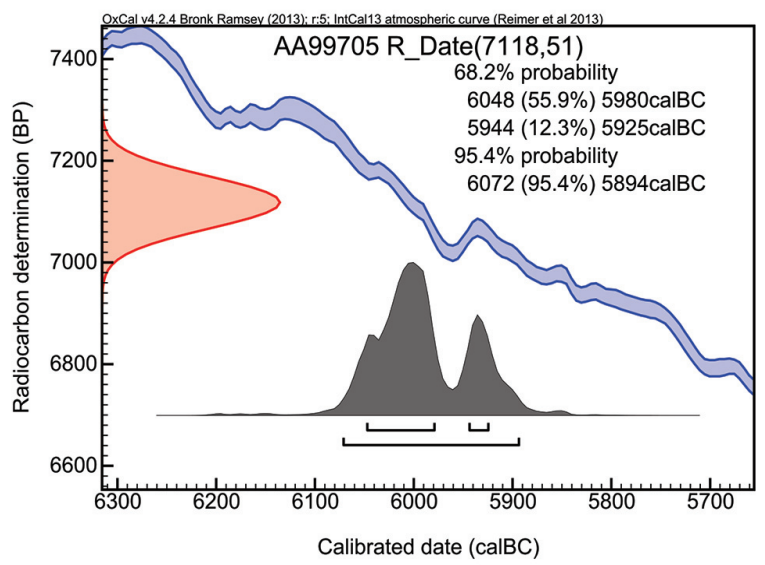

the beginning of the Holocene. The only large river in this area is the Danube, while the Sava and Drava plains experienced regular seasonal flooding, but were also covered by dense forests. Mesolithic settlements can nevertheless be expected on the high right margin of the Danube and Đakovo-Vinkovci loess plateau. However, intensive occupation of these regions from the Late Neolithic to modern times reduces the hope of finding surviving Mesolithic sites.

\section{Conclusion}

The appearance of the early Neolithic, i.e. Starčevo culture in the Sava-Drava-Danube interfluve can be placed around $6000 \mathrm{BC}$ or just slightly before, as current research and radiocarbon dates show. The earliest dates and finds come from the Sopot site situated in the south-eastern part of Slavonia. After a short period of settlement during this initial Neolithic phase, an episode of flooding probably sealed off the site for the next 1000 years. Shortly after the abandonment of Sopot site, the Zadubravlje and Galovo sites situated in the Sava valley to the west were settled. Both sites show traces of flooding, which was probably the reason why both sites were abandoned and never resettled (except for the late Bronze Age necropolis at the Galovo site). Most of the dates from Zadubravlje and Galovo group after $5850 \mathrm{BC}$,

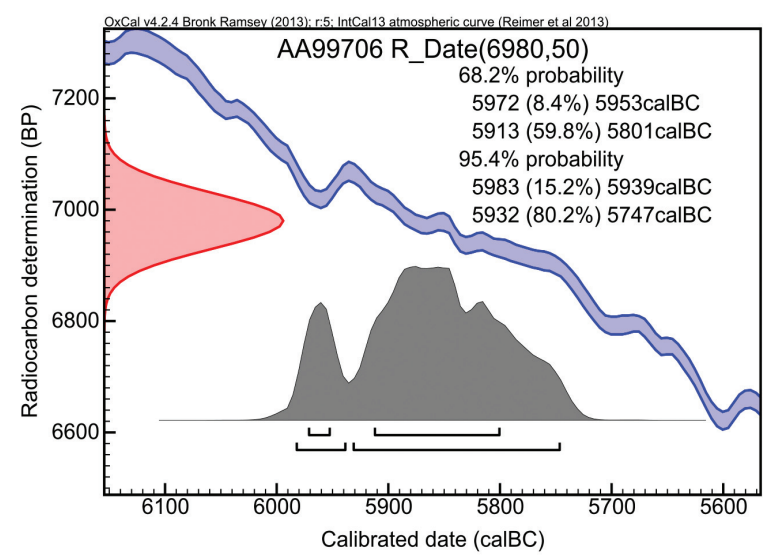

Fig. 13. ${ }^{14} \mathrm{C}$ dates for two sub-fossil samples: AA99705 = sample 25 and AA99706 = sample 151. OxCal v4.2.4 (Bronk Ramsey et al. 2013); IntCal 13 atmospheric curve (Reimer et al. 2013). 
although two older dates, slightly younger than the Sopot dates, come from the Zadubravlje site and four dates from the Galovo site. The youngest group of dates can be observed at the Galovo and Virovitica - Brekinja sites (with one date from Zadubravlje) starting after $5500 \mathrm{BC}$. The end of Starčevo culture can be expected before $5100 \mathrm{BC}$. Radiocarbon dates also indicate the north-western spread of Starčevo culture to the Drava valley around $5750 \mathrm{BC}$ and later.

Taking climatological/ecological data into consideration, the beginning of Starčevo culture can be linked to the end of the 6600-6000 BC period of Rapid Climate Change ( $8.2 \mathrm{ka}$ cal $\mathrm{BP})$ but it cannot be expected earlier than $6100 \mathrm{BC}$. Similarly, the end of Starčevo culture can be linked to the $7.1 \mathrm{ka}$ calBP event (5300-5100 BC).

There is circumstantial evidence of climatic instability in this region, i.e. excess of precipitation that can probably be linked to flooding responsible for sealing off the Sopot site and for the unfavourable conditions prior to the Drava region settlement around $5750 \mathrm{BC}$.

The white painted pottery found at Sopot and Galovo sites shows the connection to other regions of south-east Europe in the Neolithisation process. This connection is also visible in available radiocarbon dates. Weninger et alii (2014.6) give the best summary of the process: "The moment the Neolithic left the Aegean basin, which appears to have occurred not earlier than 6100 cal BC, it apparently took little more than 100 years to become established at sites in Serbia, Bulgaria, and Romania, and little more than around 200 years even to have reached the Pannonian Basin."

Although the climate was not the primary reason for cultural change, and in some cases played almost no role in it (Budja 2015; Flohr et al. 2015), it is worth noting that radiocarbon dates from early Neolithic sites of the Sava-Drava-Danube interfluve fit well between documented RCC periods; further archaeo- logical, geoarchaeological and palaeoenvironmental research is needed to firmly establish a cultural, climatological and environmental connection. The term archaeological climatology or archaeoclimatology, introduced by Fabian Welc (2016) describing a subdiscipline within geoarchaeological science, can be applied to this future interdisciplinary research.

\section{Epilogue}

During spring 2016, a small scale geoarchaeological survey in eastern Slavonia was conducted by Zagreb Institute of Archaeology and the Institute of Archaeology, Cardinal Stefan Wyszynski University in Warsaw with the cooperation of the Faculty of Geology, University of Warsaw. The survey consisted of geological sampling and a geophysical survey and was conducted at, among other places, at Slavonski Brod - Galovo and Sopot sites. At the Galovo site, a core of $9 \mathrm{~m}$ was taken, while at the Sopot site the depth of the core was $3.6 \mathrm{~m}$. Magnetic susceptibility preliminary results show an episode of drought followed by an episode of extreme wetter conditions just at the end of life at the Galovo site, while the cultural layer at Sopot site was sealed off by a pronounced wet episode. The interchange of dry and extremely wet conditions can be compared to the eastern Mediterranean periods of extreme drought during which 'flash-flood' events occurred (Weninger et al. 2009. 33). The full results of this survey will be published in the future.

\section{ACKNOWLEDGEMENTS}

This paper presents partial results of my doctoral research in the framework of Zagreb Institute of Archaeology's Archaeological landscapes and identities (A1 and A2) research programme.

I would also like to thank my colleagues Dr K. Minichreiter (Zagreb), M. Krznaric Škrivanko (City Museum Vinkovci) and Dr I. Krajcar Bronić (Rudjer Boškovic Institute, Zagreb) for all the information provided.

\section{References}

Alley R. B., Ágústsdóttir A. M. 2005. The 8k event: cause and consequences of a major Holocene abrupt climate change. Quaternary Science Reviews 24(10-11): 11231149.
Alley R. B., Mayewski P. A., Sowers T., Stuiver M., Taylor K. C. and Clark P. U. 1997. Holocene climatic instability: A prominent, widespread event $8200 \mathrm{yr}$ ago. Geology 25(6): 483-486. 
Balen J., Gerometta K. 2011. Nalazi žrtvenika i figuralne plastike starčevačke culture s lokaliteta Tomašanci - Palača. In M. Dizdar (ed.), Panonski prapovijesni osviti Zbornik radova posvećen Korneliji Minichreiter uz 65. obljetnicu života. Institut za arheologiju. Zagreb: 83-103.

Bánffy E. 2013a. The Early Neolithic in the DanubeTisza interfluve. British Archaeological Reports IS 2584. Archaeolingua, Central European Series 7. Oxford.

2013b. On Neolithic Frontiers in the Carpathian Basin. In A. Anders, G. Kulcsár (eds.), Moments in time - Papers Presented to Pál Raczky on His 60th Birthday. Budapest: 35-45.

Bánffy E., Juhász I. and Sümegi P. 2007. A prelude to the Neolithic in the Balaton region: new results to an old problem. In M. Spataro, P. Biagi (eds.), A short walk through the Balkans: the first farmers of the Carpathian basin and adjacent regions. Proceedings of the Conference held at the Institute of Archaeology UCL on June $20^{\text {th }}-22^{\text {nd }}$ 2005. Quaderno 12. Trieste: 223-237.

Bánffy E., Sümegi P. 2012. The Early Neolithic Agro-Ecological Barrier in the Carpathian Basin: A Zone for Interaction. In P. Anreiter, E. Bánffy, L. Bartosiewicz, W. Meid and C. Metzner-Nebelsick (eds.), Archaeological, Cultural and Linguistic Heritage, Festschrift for Erzsébet Jerem in Honour of her $70^{\text {th }}$ Birthday. Archaeolingua. Budapest: $57-69$.

Bauer E., Ganopolski A. and Montoya A. 2004. Simulation of the cold climate event 8200 years ago by meltwater outburst from Lake Agassiz. Paleoceanography 19(3), PA3014: 1-13.

Benito G., Macklin M. G., Panin A., Rossato S., Fontana A., Jones A. F., Machado M. J., Matlakhova E., Mozzi P. and Zielhofer C. 2015. Recurring flood distribution patterns related to short-term Holocene climatic variability. Scientific Reports 5(16398): 1-8.

Berger J.-F., Guilaine J. 2009. The 8200 cal BP abrupt environmental change and the Neolithic transition: A Mediterranean perspective. Quaternary International 200(1-2): 31-49.

Biagi P., Spataro M. 2005. New observations on the radiocarbon chronology of the Starčevo-Criş and Körös cultures. In L. Nikolova, J. Fritz and J. Higgins (eds.), Prehistoric Archaeology and Anthropological Theory and Education. Reports of Prehistoric Research Projects 6-7. International Institute of Anthropology. Salt Lake City, Karlovo: 35-40.

Biagi P., Shennan S. and Spataro M. 2005. Rapid rivers and slow seas? - New data for the radiocarbon chronology of the Balkan peninsula. In L. Nikolova, J. Fritz and J.
Higgins (eds.), Prehistoric Archaeology and Anthropological Theory and Education. Reports of Prehistoric Research Projects 6-7. International Institute of Anthropology. Salt Lake City, Karlovo: 41-52.

Bout-Roumazeilles V., Comboureu Nebout N., Peyron O., Cortijo E., Landais A. and Masson-Delmotte V. 2007. Connection between South Mediterranean climate and North African atmospheric circulation during the last 50,000 yr BP North Atlantic cold events. Quaternary Science Reviews 26(25-28): 3197-3215.

Bond G., Showers W., Cheseby M., Lotti R., Almasi P., de Menocal P., Priore P., Cullen H., Hajdas I. and Bonani G. 1997. A Pervasive Millennial-Scale Cycle in North Atlantic Holocene and Glacial Climates. Science 278: 1257-1266.

Bond G., Kromer B., Beer J., Muscheler R., Evans M. N., Showers W., Hoffmann S., Lotti-Bond R., Hajdas I. and Bonani G. 2001. Persistent Solar Influence on North Atlantic Climate During the Holocene. Science 294(5549): 2130-2136.

Bonsall C. 2007. When was the Neolithic transition in the Iron Gates? In M. Spataro, P. Biagi (eds.), A short walk through the Balkans: the first farmers of the Carpathian basin and adjacent regions. Proceedings of the Conference held at the Institute of Archaeology UCL on June 20th-22nd 2005. Quaderno 12. Trieste: 53-66.

Bonsall C., Macklin M. G., Payton R. W. and Boroneant A. 2002. Climate, floods and river gods: environmental change and the Meso-Neolithic transition in southeast Europe. Before Farming 3-4(2): 1-15.

Borić D. 2011. Adaptations and Transformations of the Danube Gorges Foragers (c. 13.000-5500 BC): An Overview. In R. Krauß (ed.), Beginnings - New Research in the Appearance of the Neolithic between Northwest Anatolia and the Carpathian Basin. Papers of the International Workshop, $8^{\text {th }} 9^{\text {th }}$ April 2009, Istanbul, MenschenKulturen-Traditione. ForschungsCluster 1, Band 1: 157-203.

Borić D., Dimitrijević V. 2007a. When did the 'Neolithic package' reach Lepenski Vir? Radiometric and faunal evidence. Documenta Praehistorica 34: 53-72.

2007b. Apsolutna hronologija i stratigrafija Lepenskog Vira. Starinar LVII: 9-55.

Borić D., French C. and Dimitrijević V. 2008. Vlasac revisited: formation processes, stratigraphy and dating. Documenta Praehistorica 35: 261-287.

Borić D., French C. A. I., Stefanović S., Dimitrijević V., Cristiani E., Gurova M., Antonović D., Allué E. and Filipović D. 2014. Late Mesolithic lifeways and deathways at Vlasac (Serbia). Journal of Field Archaeology 39(1): 4-31. 
Botić K. 2016. Climatic influences on appearance and development of Neolithic cultures in southern outskirts of Carpathian basin. Studia Quaternaria 33(1): 11-26.

Bronk Ramsey C., Scott E. M. and van der Pilcht J. 2013. Calibration for archaeological and environmental terrestrial samples in the time range $26-50 \mathrm{Ka}$ cal BP. Radiocarbon 55(4): 2021-2027.

Budja M. 2007. The 8200 calBP 'climate event' and the process of neolithisation in south-eastern Europe. Documenta Praehistorica 34: 191-201.

2009. Early Neolithic pottery dispersals and demic diffusion in Southeastern Europe. Documenta Praehistorica 36: $117-137$.

2013. Neolithic pots and potters in Europe: the end of 'demic diffusion' migratory model. Documenta Praehistorica 40: 39-55.

2015. Archaeology and rapid climate changes: from the collapse concept to a panarchy interpretative model. Documenta Praehistorica 42: 171-184.

Burić M. 2015. Problems of the Late Neolithic Absolute Chronology in Eastern Croatia. In S. Hansen, P. Raczky, A. Anders and A. Reingruber (eds.), Neolithic and Copper Age between the Carpathians and the Aegean Sea: chronologies and technologies from the $6^{\text {th }}$ to the $4^{\text {th }}$ Millennium BCE. International Workshop Budapest 2012. Arhäologie in Euroasien 31. Bonn: 143-156.

Clare L., Rohling E. J., Weninger B. and Hilpert J. 2008. Warfare in Late Neolithic/Early Chalcolithic Pisidia, southwestern Turkey. Climate induced social unrest in the late $7_{\text {th }}$ millennium cal BC. Documenta Praehistorica 35: 65-92.

Clare L., Weninger B. 2010. Social and biophysical vulnerability of prehistoric societies to Rapid Climate Change. Documenta Praehistorica 37: 283-292.

Čufar K., Grabner M., Morgós A., Martínez del Castillo E., Merela M. and de Luis M. 2014. Common climatic signals affecting oak tree-ring growth in SE Central Europe. Trees 28(5): 1267-1277.

Dimitrijević S. 1969. Starčevačka kultura u slavonskosrijemskom prostoru i problem prijelaza starijeg u srednji neolit u srpskom i hrvatskom Podunavlju. Simpozij Neolit i eneolit u Slavoniji, Vukovar, 4.-5. lipnja 1966. Actes 5. Vukovar.

1979. Sjeverna zona. In A. Benac (ed.), Praistorija jugoslavenskih zemalja II - Neolitsko doba. Akademija nauka i umjetnosti Bosne i Hercegovine. Centar za balkanološka istraživanja. Sarajevo: 229-360.
Dörfler W. 2013. Prokoško Jezero: An environmental record from a subalpine lake in Bosnia-Herzegovina. In J. Müller, K. Rassmann and R. Hofmann (eds.), Okolište 1 Untersuchungen einer spätneolithischen Siedlungskammer in Zentralbosnien. Universitätsforschungen zur prähistorischen Archäologie Band 228. Bonn, 311-340.

Draşovean F. 2007. Regional aspects in the process of Neolithisation of the Banat (south-western Romania): the settlement of Foeni-Sălaş. In M. Spataro, P. Biagi (eds.), $A$ short walk through the Balkans: the first farmers of the Carpathian basin and adjacent regions. Proceedings of the Conference held at the Institute of Archaeology UCL on June 20th-22nd 2005. Quaderno 12. Trieste: 67-76.

Dzhanfezova T., Doherty C. and Elenski N. 2014. Shaping a future of painting: the early Neolithic pottery from Dzhulyunitsa, North Central Bulgaria. Bulgarian e-Journal of Archaeology 4: 137-159.

Feurdean A., Klotz S., Mosbrugger V. and Wohlfarth B. 2008. Pollen-based quantitative reconstructions of Holocene climate variabitiy in NW Romania. Palaeogeography, Palaeoclimatology, Palaeoecology 260(3-4): 494-504.

Flohr P. 2015. Evidence of resilience to past climate change in Southwest Asia: Early farming communities and the 9.2 and 8.2 ka events. Quaternary Science Reviews 136: 23-39.

Gronenborn D. 2009. Climate fluctuations and trajectories to complexity in the Neolithic: towards a theory. $\mathrm{Do}^{-}$ cumenta Praehistorica 36: 97-110.

2014. Expansion of farming in western Eurasia, Map vers. 2014.2 - Gronenborn/Ober 2014 (RGZM).

Gurova M., Bonsall C. 2014. 'Pre-Neolithic' in Southeast Europe: a Bulgarian perspective. Documenta Praehistorica 41: 95-109.

Haas J. N., Richoz I., Tinner W. and Wick L. 1998. Synchronous Holocene climatic oscillations recorded on the Swiss Plateau and at timberline in the Alps. The Holocene 8(3): 301-309.

Hertelendi E., Kalicz N., Raczky P., Horváth F., Veres M., Svingor E., Futó I. and Bartosiewicz L. 1995. Re-evaluation of the Neolithic in Eastern Hungary based on calibrated radiocarbon dates. In G. T. Cook, D. D. Harkness, B. F. Miller and E. M. Scott (eds.), Proceedings of the 15th International ${ }^{14} \mathrm{C}$ Conference. Radiocarbon 37(2): 239 244.

Jurić I., Bogunović M., Đikić M. and Balen J. 2001. Značajke poljoprivredne proizvodnje u naseljima starčevačke kulture na prostoru između Vinkovaca i Slavonskog broda u Hrvatskoj. Društvena istraživanja 6(56): 1131-1158. 
Krajcar Bronić I. 2011. Određivanje starosti metodom ${ }^{14} \mathrm{C}$ i primjer datiranja dvaju neolitičkih naselja u Hrvatskoj. In M. Dizdar (ed.), Panonski prapovijesni osviti - Zbornik radova posvećen Korneliji Minichreiter uz 65. obljetnicu života. Institut za arheologiju. Zagreb: 175-189.

Krajcar Bronić I., Minichreiter K., Obelić B. and Horvatinčić N. 2002. Zadubravlje-Dužine - the oldest early Neolithic (Starčevo culture) settlement in Croatia. In ${ }^{14} \mathrm{C}$ and Archaeology: Fourth Symposium, St. Catherine's Collegue, Oxford, 9-14 April 2002 (abstract): 17-18.

Krajcar Bronić I., Obelić B., Horvatinčić N., Barešić J., Sironić A. and Minichreiter K. 2010. Radiocarbon application in environmental science and archaeology in Croatia. Nuclear Instruments and Methods in Physics Research A 619: 491-496.

Krajcar Bronić I., Minichreiter K. 2007. ${ }^{14} \mathrm{C}$ dating of early Neolithic settement Galovo near Slavonski Brod in Northern Croatia. Nuclear Instruments and Methods in Physics Research A 580: 714-716.

2011. ${ }^{14} \mathrm{C}$ dating of Neolithic cultures in Croatia. In V. Nikolov, K. Bacvarov and H. Popov (eds.), Interdisziplinäre Forschungen zum Kulturerbe auf der Balkanhalbinsel. Nice AN. Sofia: 43-52.

Krauß R. 2010. Erneute Gedanken zur regionalen Gliederung des balkanischen Frühneolithikums. In J. Šuteková, P. Pavúk, P. Kalábková and B. Kovár (eds.), Panta rhei Studies on the Chronology and Cultural Development of the South-Eastern and Central Europe in Earlier Prehistory Presented to Juraj Pavúk on the Occasion of his 75 th Birthday. Studia Archaeologica et Mediaevalia XI. Bratislava: 35-58.

2011. On the "Monochrome" Neolithic in Southeast Europe. In R. Krauß (ed.), Beginnings - New Research in the Appearance of the Neolithic between Northwest Anatolia and the Carpathian Basin. Papers of the International Workshop, 8th-9th April 2009, Istanbul. Menschen-Kulturen-Traditionen. Forschungs Cluster 1 Band 1. Istanbul: 109-125.

2014. The Mesolithic-Neolithic Transition in the Carpathian Basin. In R. Krauß, H. Floss (eds.), Southeast Europe before Neolithisation. Proceedings of the International Workshop within the Collaborative Research Centres SFB 1070 "RessourcenKulturen", Schloss Hohentübingen, $9^{\text {th }}$ of May 2014. RessourcenKulturen Bd. 1. Tübingen: 193-222.

Krauß R., Elenski N., Weninger B., Clare L., Çakırlar C. and Zidarov P. 2014. Beginnings of the Neolithic in Southeast Europe: the Early Neolithic sequence and absolute dates from Džuljunica-Smărdeš (Bulgaria). Documenta Praehistorica 41: 51-77.
Krznarić Škrivanko M. 2009. Lokalitet - Sopot. Hrvatski arheološki godišnjak 5: 89-92.

2011. Radiokarbonski datumi uzoraka sa Sopota. In M. Dizdar (ed.), Panonski prapovijesni osviti - Zbornik radova posvećen Korneliji Minichreiter uz 65. obljetnicu života. Institut za arheologiju. Zagreb: 209-225.

2015. Rezultati Dimitrijevićevih istraživanja Sopota u svjetlu novih istraživanja / The results of Dimitrijević's excavations at Sopot in light of recent research. Opuscula archaeologica 37/38(2013/2014): 371-395.

Kuper R., Kröpelin S. 2006. Climate-Controlled Holocene Occupation in the Sahara: Motor of Africa's Evolution. Science 313: 803-807.

Lawson I. T., Al-Omar S., Tzedakis P. C., Bryant C. L. and Christanis K. 2005. Lateglacial and Holocene vegetation history at Nisi Fen and the Boras mountains, northern Greece. The Holocene 15: 873-887.

Lespez L., Tsirtsoni Z., Darcque P., Koukouli-Chryssanthaki H., Malamidou D., Treuil R., Davidson R., Kourtessi-Philippakis G. and Oberlin C. 2013. The lowest levels at Dikli Tash, northern Greece: a missing link in the Early Neolithic of Europe. Antiquity 87: 30-45.

Luca S. A., Suciu C. I. 2008. Migrations and local evolution in the Early Neolithic in Transylvania: The typological-stylistic analysis and the radiocarbon data. In M. Spataro, P. Biagi (eds.), A short walk through the Balkans: the first farmers of the Carpathian basin and adjacent regions. Proceedings of the Conference held at the Institute of Archaeology UCL on June 20th-22nd 2005. Quaderno 12. Trieste: 77-87.

Luca S. A., Diaconescu D. and Suciu C. I. 2008. Archaeological research in Miercurea Sibiului - Petriş (Sibiu County, Roumania): the Starčevo-Criş level during 1997-2005 (a preliminary report). Documenta Praehistorica 35: 352-343.

Luca S. A., Suciu C. I. and Dumitrescu-Chioar F. 2011. Catalogue of the Early Neolithic settlements in Western part of Romania - Transylvania, Banat, Crişana, Maramureş, Oltenia and Western Muntenia. In S. A. Luca, C. Suciu (eds.), The First Neolithic Sites in Central/South-East European Transect, Volume II - Early Neolithic (Starčevo-Cris) Sites on the territory of Romania. British Archaeological Reports IS 2188. Archaeopress. Oxford: 79-132.

Magny M., Bégeot C., Guiot J. and Peyron 0. 2003. Contrasting patterns of hydrological changes in Europe in response to Holocene climate cooling phases. Quaternary Science Reviews 22(15-17): 1589-1596.

Magny M., Combourieu Nebout N. 2013. Holocene changes in environment and climate in the central Mediterranean 
as reflected by lake and marine records. Climate of the Past 9: 1447-1454.

Marković Z. 1994. Sjeverna Hrvatska od neolita do brončanog doba - Problem kontinuiteta stanovništva $i$ kultura sjeverne Hrvatske od ranog neolita do početka brončanog doba. Muzej grada Koprivnice. Koprivnica.

Marino G., Rohling E. J., Sangiorgi F., Hayes A., Casford J. L., Lotter A. F., Kucera M. and Brinkhuis H. 2009. Early and middle Holocene in the Aegean Sea: interplay between high and low latitude climate variability. Quaternary Science Reviews 28(27-28): 3246-3262.

Mayewski P. A., Meeker L. D., Twickler M. S., Whitow S., Yang Q., Lyons W. B. and Prentice M. 1997. Major features and forcing of high-latitude northern hemisphere atmospheric circulation using a 110,000-year-long glaciochemical series. Journal of Geophisical Research 102(C12): $26,345-26,366$

Mayewski P. A. and 15 co-authors. 2004. Holocene climate variability. Quaternary Research 62(3): 243-255.

Migowski C., Mordechai S., Sushma P., Negendank J. F. W. and Agnon A. 2006. Holocene climate variability and cultural evolution in the Near East from the Dead Sea sedimentary record. Quaternary Research 66(3): 421-431.

Minichreiter K. 1992. Starčevačka kultura u sjevernoj Hrvatskoj. Dissertationes et monographiae 1. Zagreb.

1993. Arhitektura starčevačkog naselja kod Zadubravlja. Izdanja Hrvatskog arheološkog društva 16: 97-111.

2001. The architecture of Early and Middle Neolithic settlements of the Starčevo culture in Northern Croatia. Documenta Praehistorica 28: 199-214.

2007a. Slavonski Brod, Galovo - Deset godina arheoloških istraživanja. Monografije Instituta za arheologiju I. Zagreb.

2007b. Bijelo slikani linear A stupanj starčevačke kulture u Hrvatskoj / The White-painted Linear A Phase of the Starčevo Culture in Croatia. Prilozi Instituta za arheologiju u Zagrebu 24: 21-34.

2007c. The first farmers of northern Croatia. In M. Spataro, P. Biagi (eds.), A short walk through the Balkans: the first farmers of the Carpathian basin and adjacent regions. Proceedings of the Conference held at the Institute of Archaeology, University College London on June $20^{\text {th }}-22^{\text {nd }} 2005$. Quaderno 12 . Trieste: $171-181$.

2010. Nadzemni objekti u naseljima starčevačke kulture / Above-ground Structures in the Settlements of the Starčevo Culture. Prilozi Instituta za arheologiju $u$ Zagrebu 27: 15-32.
2011. Slavonski Brod, Galovo, arheološka istraživanja 2010. g. Annales Instituti Archaeologici VII: 34-36.

2012. Slavonski Brod, Galovo, arheološka istraživanja 2011. g. Annales Instituti Archaeologici VIII: 18-22.

2013. Slavonski Brod, Galovo, arheološka istraživanja 2012. g. Annales Instituti Archaeologici IX: 26-30.

2014. Slavonski Brod, Galovo, arheološka istraživanja 2013. g. Annales Instituti Archaeologici X: 69-72.

2015. Slavonski Brod, Galovo, arheološka istraživanja 2014. g. Annales Instituti Archaeologici XI: 33-37.

Minichreiter K., Botić K. 2010. Early Neolithic burials of Starčevo culture at Galovo, Slavonski Brod (Northern Croatia). Documenta Praehistorica 37: 105-124.

Minichreiter K., Krajcar Bronić I. 2006. Novi radiokarbonski datumi rane starčevačke kulture u Hrvatskoj. Prilozi Instituta za arheologiju u Zagrebu 23: 5-16.

Náfrádi K., Barna J. P. and Sümegi P. 2015. Geoarchaeological investigations at Sormás-Török-földek, a Neolithic site in Southwestern Transdanubia, Hungary. Journal of Archaeological Science: Reports 1: 8-20.

Nikolova L. 2007. Toward an evolutionary model of gradual development of social complexity among the Neolithic pottery communities in the Balkans (cultural-chronological and cultural-anthropological problems). In M. Spataro, P. Biagi (eds.), A short walk through the Balkans: the first farmers of the Carpathian basin and adjacent regions. Proceedings of the Conference held at the Institute of Archaeology, University College London on June $20^{\text {th }}-22^{\text {nd }} 2005$. Quaderno 12 . Trieste: $89-102$.

Obelić B., Krajcar Bronić I. and Horvatinčić N. 2002. Rudjer Bošković Institute radiocarbon measurements XV. Radiocarbon 44(2): 601-630.

Pearson C., Ważny T., Kuniholm P. I., Botić K., Durman A. and Seufer K. 2014. Potential for a new multi-millennial tree-ring chronology from sub-fossil Balkan river oaks. Radiocarbon 56(4): S51-S59.

Perry C. A., Hsu K. J. 2000. Geophysical, archaeological and historical evidence support a solar-output model for climate change. Proceedings of the National Academy of Sciences USA 97(23): 12433-12438.

Reimer P. J. and 29 co-authors. 2013. IntCal13 and Marine13 radiocarbon age calibration curves, $0-50,000$ years cal BP. Radiocarbon 55(4): 1869-1887.

Reimer H., Lange M. and Kindermann K. 2013. When the Desert Dried Up: Late Prehistoric Cultures and Contacts in Egypt and Northern Sudan. In D. Raue, S. J. Seidl- 
mayer, P. Speiser (eds.), The First Cataract of the Nile: One Region - Diverse Perspectives. Sonderschrift 36. Deutsches Archäologisches Institut. Kairo: 157-184.

Revel M., Ducassou E., Grousset F. E., Bernasconi S. M., Migeon S., Revillon S., Mascle J., Murat A., Zaragosi S. and Bosch D. 2010. 100,000 Years of African monsoon variability recorded in sediments of the Nile margin. Quaternary Science Reviews 29(11-12): 1342-1362.

Rohling E. J., Mayewski P. A., Abu-Zeid R. H., Casford J. S. L. and Hayes A. 2002. Holocene atmosphere-ocean interactions: records from Greenland and the Aegean Sea. Climate Cynamics 18: 587-593.

Salisbury R. B., Bácsmegi G. and Sümegi P. 2013. Preliminary environmental historical results to reconstruct prehistoric human-environmental interaction in Eastern Hungary. Central European Journal of Geosciences 5(3): 331-343.

Sekelj-Ivančan T., Balen J. 2007. Brekinja. In D. Sabolić (ed.), Zapadna Virovitička obilaznica - Zaštitna arheološka istraživanja 2005./2006. godine. Gradski muzej Virovitica. Virovitica: 21-26.

Siani G., Magny M., Paterne M., Debret M. and Fontugne M. 2013. Paleohydrology reconstruction and Holocene climate variability in the South Adriatic Sea. Climate of the Past 9: 499-545.

Stojanovski D., Nacev T., Arzarello M. 2014. Pottery typology and the monochrome Neolithic phase in the Republic of Macedonia. In W. Schier and F. Draşovean (eds.), The Neolithic and Eneolithic in Southeast Europe, New approaches to dating and cultural dynamics in the $6^{\text {th }}$ to $4^{\text {th }}$ millennium $B C$. Prähistorische Archölogie in Südosteuropa Bd. 28. Rahden/Westf.: 9-27.

Šimić J. 2007a. Zaštitno istraživanje prapovijesnog nalazišta Staro Valpovo pokraj Belišća. Obavijesti Hrvatskog arheološkog društva XXXIX(1): 26-35.

2007b. Lokalitet: Belišće - Staro Valpovo. Hrvatski arheološki godišnjak 3/2006: 9-11.

2012. Šetnje slavonskom i baranjskom prapoviješću. Osijek.

Thomas W. R., Wolff E. W., Mulvaney R., Steffensen J. P., Johnsen S. J., Arrowsmith C., White J. W. C., Vaughn B. and Popp T. 2007. The $8.2 \mathrm{ka}$ event from Greenland ice cores. Quaternary Science Reviews 26(1-2): 70-81.

Tinner W., Lotter A. F. 2001. Central European vegetation response to abrupt climate change at $8.2 \mathrm{ka}$. Geology 29 (6): 551-554.
2006. Holocene expansions of Fagus silvatica and Abies alba in Central Europe: where are we after eight decades of debate? Quaternary Science Reviews 25(5-6): 526549 .

Welc F. 2016. Editorial. Studia Quaternaria 33(1): 3.

Weninger B., Alram-Stern E., Bauer E., Clare L., Danzeglocke U., Jöris 0., Kubatzki C., Rollefson G., Todorova H. and van Andel T. 2006. Climate forcing due to the $8200 \mathrm{cal} \mathrm{yr}$ BP event observed at Early Neolithic sites in the eastern Mediterranean. Quaternary Research 66(3): 401-420.

Weninger B. and 18 co-authors. 2009. The Impact of Rapid Climate Change on prehistoric societies during the Holocene in the Eastern Mediterranean. Documenta Praehistorica 36: 7-59.

Weninger B., Clare L., Gerritsen F., Horejs B., Krauss R., Linstädter J., Özbal R. and Rohling E. J. 2014. Neolithisation of the Aegean and Southeast Europe during the 6600-6000 cal BC period of Rapid Climate Change. Documenta Praehistorica 41: 1-31.

Weninger B., Clare L. 2011. Holocene Rapid Climate Change in the Eastern Mediterranean. An Emerging Archaeological Climate Research Programme. In R. Krauß (ed.), Beginnings - New Research in the Appearance of the Neolithic between Northwest Anatolia and the Carpathian Basin. Papers of the International Workshop $8^{\text {th-9 }} 9^{\text {th }}$ April 2009, Istanbul. Menschen - Kulturen - Traditionen, Studien aus den Forschungsclustern des Deutschen Archäologischen Instituts Band 1. Istanbul: 11-22.

Weninger B., Harper T. 2015. The Geographic Corridor for Rapid Climate Change in Southeast Europe and Ukraine. In E. Schultze (ed.), Neolithic and Copper Age between the Carpathians and the Aegean Sea. Archäologie in Eurasien 31. Berlin: 485-515.

Whittle A., Bartosiewicz L., Borić D., Pettitt P. and Richards M. 2002. In the beginning: new radiocarbon dates for the Early Neolithic in northern Serbia and south-east Hungary. Antaeus 25: 63-117.

Willis K. J. 1992. The late Quaternary vegetational history of northwestern Greece II. Rezina marsh. New Phytologist 121: 119-138.

Zielhofer C., Clare L., Rollefson G., Wächter S., Hoffmeister D., Bareth G., Roettig C., Bullmann H., Schneider B., Berke $H$. and Weninger B. 2012. The decline of the early Neolithic population center of 'Ain Ghazal and corresponding earth-surface processes, Jordan Rift Valley. Quaternary Research 78(3): 427-441. 


\begin{tabular}{|c|c|c|c|c|c|c|}
\hline Site & Lab code & Material and context & $\begin{array}{l}{ }^{14 C} \text { Age } \\
\text { (BP) }\end{array}$ & $\mid \begin{array}{c}\delta^{13} \mathrm{C} / \\
{ }^{12} \mathrm{C}(\% \circ)\end{array}$ & $\begin{array}{c}\text { cal BC } \\
(2 \sigma)\end{array}$ & Reference \\
\hline Sopot & Beta 251909 & $\begin{array}{l}\text { tooth from SU } 80 \\
\text { (sq. } / 25) \text { : layer before } \\
\text { sterile ground }\end{array}$ & $7120 \pm 50$ & -20.0 & $6072-5897$ & $\begin{array}{l}\text { Krznarić Škrivanko 2011.215, } \\
\text { Tab. } 3\end{array}$ \\
\hline Sopot & Beta 251911 & $\begin{array}{l}\text { tooth from SU } 143 \\
\text { (sq. J37): layer before } \\
\text { sterile ground }\end{array}$ & $7110 \pm 50$ & -19.7 & $6067-5892$ & $\begin{array}{l}\text { Krznarić Śkrivanko 2011.215, } \\
\text { Tab. } 3\end{array}$ \\
\hline Sopot & Beta 251910 & $\begin{array}{l}\text { tooth from SU } 519 \\
\text { (sq. K35): pit-dwelling }\end{array}$ & $7100 \pm 50$ & -20.5 & $6065-5886$ & $\begin{array}{l}\text { Krznarić Škrivanko 2011.215, } \\
\text { Tab. 3; Burić 2015.145, Tab. } 2\end{array}$ \\
\hline $\begin{array}{l}\text { Zadubravlje - } \\
\text { Dužine }\end{array}$ & Z-2924 & $\begin{array}{l}\text { charcoal from } \\
\text { well } 11 \text { (sq. C/19; } \\
3.90-4.10 m \text { depth) }\end{array}$ & $7620 \pm 140$ & & $6850-6100$ & $\begin{array}{l}\text { Obelić et al. 2002.620; Krajcar } \\
\text { Bronić et al. 2002.18; Minich- } \\
\text { reiter, Krajcar Bronić 2006.14, } \\
\text { Fig. 5; Minichreiter 2001.207; } \\
\text { Krajcar Bronić 2011.183,185, Fig. } \\
\text { 5; Krajcar Bronić, Minichreiter } \\
\text { 2011.47, Fig. } 3\end{array}$ \\
\hline $\begin{array}{l}\text { Zadubravlje - } \\
\text { Dužine }\end{array}$ & Z-2923 & $\begin{array}{l}\text { charcoal from south- } \\
\text { east part of the pit- } \\
\text { dwelling } 10 \\
\text { (sq. D-E/15) }\end{array}$ & $6995 \pm 115$ & & $6067-5666$ & $\begin{array}{l}\text { Obelić et al. 2002.620; Krajcar } \\
\text { Bronić et al. 2002.18; Minich- } \\
\text { reiter, Krajcar Bronić 2006.14, } \\
\text { Fig. 5; Minichreiter 2001.205; } \\
\text { Krajcar Bronić 2011.185, Fig. 5; } \\
\text { Krajcar Bronić, Minichreiter } \\
\text { 2011.47, Fig. } 3\end{array}$ \\
\hline $\begin{array}{l}\text { Zadubravlje - } \\
\text { Dužine }\end{array}$ & Z-3931 & $\begin{array}{l}\text { charcoal from work- } \\
\text { ing pit } 19 \text { - workshop } \\
\text { for stone tools and } \\
\text { weapons production } \\
\text { (sq. D/11) }\end{array}$ & $6919 \pm 102$ & & $5991-5641$ & $\begin{array}{l}\text { Krajcar Bronić 2011.185, Fig. 5; } \\
\text { Krajcar Bronić, Minichreiter } \\
\text { 2011.47, Fig. } 3\end{array}$ \\
\hline $\begin{array}{l}\text { Zadubravlje - } \\
\text { Dužine }\end{array}$ & Z-3930 & $\begin{array}{l}\text { charcoal from work- } \\
\text { ing pit } 12 \text { that con- } \\
\text { tained several kilns } \\
\text { (sq. } \mathrm{A} / 2 \mathrm{O}-\mathrm{A} / 21 \text { ) }\end{array}$ & $6770 \pm 110$ & & $5884-5491$ & $\begin{array}{l}\text { Krajcar Bronić 2011.185, Fig. 5; } \\
\text { Krajcar Bronić, Minichreiter } \\
\text { 2011.47, Fig. } 3\end{array}$ \\
\hline $\begin{array}{l}\text { Zadubravlje - } \\
\text { Dužine }\end{array}$ & Z-2921 & $\begin{array}{l}\text { charcoal from } \\
\text { pit-dwelling } 6 \\
\text { (sq. A/14-A/15) }\end{array}$ & $6710 \pm 115$ & & $5873-5470$ & $\begin{array}{l}\text { Obelić et al. 2002.620; Krajcar } \\
\text { Bronić et al. 2002.18; Minich- } \\
\text { reiter, Krajcar Bronić 2006.14, } \\
\text { Fig. 5; Krajcar Bronić 2011.185, } \\
\text { Fig. 5; Krajcar Bronić, Minich- } \\
\text { reiter 2011.47, Fig. } 3\end{array}$ \\
\hline $\begin{array}{l}\text { Zadubravlje - } \\
\text { Dužine }\end{array}$ & Z-2922 & $\begin{array}{l}\text { charcoal from } \\
\text { southwest part of the } \\
\text { pit-dwelling } 9 \\
\text { (sq. } \mathrm{A} / 18 \text { ) }\end{array}$ & $6705 \pm 95$ & & $5775-5477$ & $\begin{array}{l}\text { Obelić et al. 2002.620; Krajcar } \\
\text { Bronić et al. 2002.18; Minich- } \\
\text { reiter, Krajcar Bronić 2006.14, } \\
\text { Fig. 5; Minichreiter 2001.203; } \\
\text { Krajcar Bronić 2011.185, Fig. 5; } \\
\text { Krajcar Bronić, Minichreiter } \\
\text { 2011.47, Fig. } 3\end{array}$ \\
\hline $\begin{array}{l}\text { Zadubravlje - } \\
\text { Dužine }\end{array}$ & Z-3929 & $\begin{array}{l}\text { charcoal from the } \\
\text { south pit-dwelling } 10 \\
\text { (sq. E/15) }\end{array}$ & $6673 \pm 75$ & & $5710-5486$ & $\begin{array}{l}\text { Krajcar Bronić 2011.185, Fig. 5; } \\
\text { Krajcar Bronić, Minichreiter } \\
\text { 2011.47, Fig. } 3\end{array}$ \\
\hline $\begin{array}{l}\text { Zadubravlje - } \\
\text { Dužine }\end{array}$ & Z-2925 & $\begin{array}{l}\text { charcoal from work- } \\
\text { ing pit } 12 \\
\text { (sq. } A / 20-21 \text { ) }\end{array}$ & $6260 \pm 130$ & & $5481-4858$ & $\begin{array}{l}\text { Obelić et al. 2002.620; Krajcar } \\
\text { Bronić et al. 2002.18; Minich- } \\
\text { reiter, Krajcar Bronić 2006.14, } \\
\text { Fig. 5; Minichreiter 2001.204; } \\
\text { Krajcar Bronić 2011.185, Fig. 5; } \\
\text { Krajcar Bronić, Minichreiter } \\
\text { 2011.47, Fig. } 3\end{array}$ \\
\hline $\begin{array}{l}\text { Slavonski } \\
\text { Brod - } \\
\text { Galovo }\end{array}$ & Z-5043 & $\begin{array}{l}\text { charcoal from } \\
\text { burial pit } 2013 \text {, } \\
\text { sq. J/6a }\end{array}$ & $7358 \pm 114$ & & $6431-6025$ & $\begin{array}{l}\text { Minichreiter } 2013.27 \text { (only par- } \\
\text { tial date published; BP age } \\
\text { first published here) }\end{array}$ \\
\hline
\end{tabular}

Tab. 1. Starčevo culture ${ }^{14}$ C dates in northern Croatia. OxCal v4.2.4 (Bronk Ramsey et al. 2013); IntCal 13 atmospheric curve (Reimer et al. 2013). 


\begin{tabular}{|c|c|c|c|c|c|c|}
\hline Site & Lab code & Material and context & $\begin{array}{c}{ }^{14 C} \text { Age } \\
\text { (BP) }\end{array}$ & $\begin{array}{c}\delta^{13} \mathrm{C} / \\
{ }^{12} \mathrm{C}(\% \circ)\end{array}$ & $\begin{array}{c}\text { cal BC } \\
(2 \sigma)\end{array}$ & Reference \\
\hline $\begin{array}{l}\text { Slavonski } \\
\text { Brod - } \\
\text { Galovo }\end{array}$ & Z-5044 & $\begin{array}{l}\text { charcoal from } \\
\text { burial pit } 2013 \text {, } \\
\text { sq. } / / 6 a\end{array}$ & $7076 \pm 158$ & & $6250-5647$ & $\begin{array}{l}\text { Minichreiter 2013.27 (only par- } \\
\text { tial date published; BP age } \\
\text { first published here) }\end{array}$ \\
\hline $\begin{array}{l}\text { Slavonski } \\
\text { Brod - } \\
\text { Galovo }\end{array}$ & Z-4357 & $\begin{array}{l}\text { charcoal from a small } \\
\text { pit } 323 \text { (sq. J/10-a,b, } \\
\text { I/10-c,d) under the } \\
\text { hearth SU } 1681 \\
\text { (sq. J/10-b) } \\
\end{array}$ & $7067 \pm 152$ & & $6234-5664$ & $\begin{array}{l}\text { Minichreiter, Botić 2010.120, } \\
\text { Fig. 14; Krajcar Bronić, Minich- } \\
\text { reiter 2011.46, Fig. } 2\end{array}$ \\
\hline $\begin{array}{l}\text { Slavonski } \\
\text { Brod - } \\
\text { Galovo }\end{array}$ & Z-3586 & $\begin{array}{l}\text { charcoal from the } \\
\text { western cult structure } \\
89 \text { (sq. F/12-d) }\end{array}$ & $7060 \pm 150$ & & $6227-5668$ & $\begin{array}{l}\text { Minichreiter, Krajcar Bronić } \\
\text { 2006.8, Fig. 2; Minichreiter } \\
\text { 2007a.192, Fig. 1; Krajcar Bro- } \\
\text { nić, Minichreiter 2007.716; Mi- } \\
\text { nichreiter, Botić 2010.120, Fig. } \\
\text { 14; Krajcar Bronić 2011.182, 184, } \\
\text { Fig. 4; Krajcar Bronić, Minich- } \\
\text { reiter 2011.46, Fig. } 2\end{array}$ \\
\hline $\begin{array}{l}\text { Slavonski } \\
\text { Brod - } \\
\text { Galovo }\end{array}$ & Z-3584 & $\begin{array}{l}\text { charcoal from the } \\
\text { western cult structure } \\
149 \text { (sq. E/11-a) }\end{array}$ & $7000 \pm 140$ & & $6205-5634$ & $\begin{array}{l}\text { Minichreiter, Krajcar Bronić } \\
\text { 2006.8, Fig. 2; Minichreiter } \\
\text { 2007a.192, Fig. 1; Krajcar Bro- } \\
\text { nić, Minichreiter 2007.716; Mi- } \\
\text { nichreiter, Botić 2010.120, Fig. } \\
\text { 14; Krajcar Bronić 2011.182, 184, } \\
\text { Fig. 4; Krajcar Bronić, Minich- } \\
\text { reiter 2011.46, Fig. } 2\end{array}$ \\
\hline $\begin{array}{l}\text { Slavonski } \\
\text { Brod - } \\
\text { Galovo }\end{array}$ & Z-3574 & $\begin{array}{l}\text { charcoal from pit- } \\
\text { dwelling } 205 / \text { kiln } 752 \\
\text { (sq. I/13a,c) }\end{array}$ & $6875 \pm 35$ & & $5842-5676$ & $\begin{array}{l}\text { Minichreiter, Krajcar Bronić } \\
\text { 2006.8, Fig. 2; Minichreiter } \\
\text { 2007a.192, Fig. 1; Krajcar Bro- } \\
\text { nić, Minichreiter 2007.716; Mi- } \\
\text { nichreiter, Botić 2010.120, Fig. } \\
\text { 14; Krajcar Bronić 2011.182, 184, } \\
\text { Fig. 4; Krajcar Bronić, Minich- } \\
\text { reiter 2011.46, Fig. } 2\end{array}$ \\
\hline $\begin{array}{l}\text { Slavonski } \\
\text { Brod - } \\
\text { Galovo }\end{array}$ & Z-3587 & $\begin{array}{l}\text { charcoal from the } \\
\text { western cult structure } \\
389 \text { (sq. G/12-a) }\end{array}$ & $6865 \pm 65$ & & $5887-5640$ & $\begin{array}{l}\text { Minichreiter, Krajcar Bronić } \\
\text { 2006.8, Fig. 2; Minichreiter } \\
\text { 2007a.192, Fig. 1; Krajcar Bro- } \\
\text { nić, Minichreiter 2007.716; Mi- } \\
\text { nichreiter, Botić 2010.120, Fig. } \\
\text { 14; Krajcar Bronić 2011.182, 184, } \\
\text { Fig. 4; Krajcar Bronić, Minich- } \\
\text { reiter 2011.46, Fig. } 2\end{array}$ \\
\hline $\begin{array}{l}\text { Slavonski } \\
\text { Brod - } \\
\text { Galovo }\end{array}$ & Beta 318679 & $\begin{array}{l}\text { charcoal from SU } \\
2243 \text { (sq. I/6b), fill of } \\
\text { the burial pit }\end{array}$ & $6860 \pm 40$ & -24.8 & $5838-5666$ & $\begin{array}{l}\text { Minichreiter } 2012.20 \text { (only par- } \\
\text { tial date published; BP age } \\
\text { first published here) }\end{array}$ \\
\hline $\begin{array}{l}\text { Slavonski } \\
\text { Brod - } \\
\text { Galovo }\end{array}$ & Z-3575 & $\begin{array}{l}\text { charcoal (loom beam) } \\
\text { from pit-dwelling } 205 \\
\text { (sq. I/13a) }\end{array}$ & $6850 \pm 60$ & & $5873-5635$ & $\begin{array}{l}\text { Minichreiter, Krajcar-Bronić } \\
\text { 2006.8, Fig. 2; Minichreiter } \\
\text { 2007a.192, Fig. 1; Krajcar Bro- } \\
\text { nić, Minichreiter 2007.716; Mi- } \\
\text { nichreiter, Botić 2010.120, Fig. } \\
\text { 14; Krajcar Bronić 2011.182, 184, } \\
\text { Fig. 4; Krajcar Bronić, Minich- } \\
\text { reiter 2011.46, Fig. } 2\end{array}$ \\
\hline $\begin{array}{l}\text { Slavonski } \\
\text { Brod - } \\
\text { Galovo }\end{array}$ & Beta 318678 & $\begin{array}{l}\text { charcoal from kiln SU } \\
258 \text { (sq. I/13-b,d) in } \\
\text { pit-dwelling SU } 205\end{array}$ & $6840 \pm 40$ & -23.8 & $5808-5642$ & first published here \\
\hline
\end{tabular}

Tab. 1. continue 


\begin{tabular}{|c|c|c|c|c|c|c|}
\hline Site & Lab code & Material and context & $\begin{array}{c}{ }^{14} \mathrm{C} \text { Age } \\
\text { (BP) }\end{array}$ & $\begin{array}{c}\delta^{13} \mathrm{C} / \\
{ }^{12} \mathrm{C}(\% \circ)\end{array}$ & $\begin{array}{c}\text { cal BC } \\
(2 \sigma)\end{array}$ & Reference \\
\hline $\begin{array}{l}\text { Slavonski } \\
\text { Brod - } \\
\text { Galovo }\end{array}$ & Z-2936 & $\begin{array}{l}\text { charcoal from kiln } \\
\text { o32, pit-dwelling } 9 \\
\text { (sq. C/3), contains } 3 \\
\text { skeletal burials }\end{array}$ & $6835 \pm 110$ & & $5981-5557$ & $\begin{array}{l}\text { Obelić et al. 2002.616; Krajcar } \\
\text { Bronić et al. 2002.18; Minich- } \\
\text { reiter, Krajcar Bronić 2006.8, } \\
\text { Fig. 2; Minichreiter 2007a.192, } \\
\text { Fig. 1; Krajcar Bronić, Minich- } \\
\text { reiter 2007.716; Minichreiter, } \\
\text { Botić 2010.120, Fig. 14; Krajcar } \\
\text { Bronić 2011.182, 184, Fig. 4; } \\
\text { Krajcar Bronić, Minichreiter } \\
\text { 2011.46, Fig. } 2\end{array}$ \\
\hline $\begin{array}{l}\text { Slavonski } \\
\text { Brod - } \\
\text { Galovo }\end{array}$ & Z-3588 & $\begin{array}{l}\text { charcoal from pit- } \\
\text { dwelling } 155 \\
\text { (sq. G/13a) }\end{array}$ & $6820 \pm 70$ & & $5876-5618$ & $\begin{array}{l}\text { Minichreiter, Krajcar Bronić } \\
\text { 2006.8, Fig. 3; Minichreiter } \\
\text { 2007a.192, Fig. 1; Krajcar } \\
\text { Bronić, Minichreiter 2007.716; } \\
\text { Minichreiter, Botić 2010.120, } \\
\text { Fig. 14; Krajcar Bronić 2011.182, } \\
\text { 184, Fig. 4; Krajcar Bronić, Mi- } \\
\text { nichreiter 2011.46, Fig. } 2\end{array}$ \\
\hline $\begin{array}{l}\text { Slavonski } \\
\text { Brod - } \\
\text { Galovo }\end{array}$ & Z-3801 & $\begin{array}{l}\text { charcoal from a kiln } \\
\text { SU } 181 \text { (sq. G/12-a, } \\
\text { G/13-b) in pit } 155\end{array}$ & $6750 \pm 70$ & & $5769-5531$ & $\begin{array}{l}\text { Krajcar Bronić et al. 2010.495, } \\
\text { Fig. 3; Minichreiter, Botić } 2010 . \\
\text { 120, Fig. 14; Krajcar Bronić } 2011 . \\
\text { 182, 184, Fig. 4; Krajcar Bronić, } \\
\text { Minichreiter 2011.46, Fig. } 2\end{array}$ \\
\hline $\begin{array}{l}\text { Slavonski } \\
\text { Brod - } \\
\text { Galovo }\end{array}$ & Z-3924 & $\begin{array}{l}\text { charcoal from a burial } \\
\text { pit } 9 \text { (sq. C/4) }\end{array}$ & $6726 \pm 147$ & & $5975-5380$ & $\begin{array}{l}\text { Krajcar Bronić et al. 2010.495, } \\
\text { Fig. 3; Minichreiter, Botić } 2010 . \\
\text { 120, Fig. 14; Krajcar Bronić } 2011 . \\
\text { 182, 184, Fig. 4; Krajcar Bronić, } \\
\text { Minichreiter 2011.46, Fig. } 2\end{array}$ \\
\hline $\begin{array}{l}\text { Slavonski } \\
\text { Brod - } \\
\text { Galovo }\end{array}$ & Z-3803 & $\begin{array}{l}\text { charcoal from pit- } \\
\text { dwelling } 207, \text { bottom } \\
\text { near the kiln } 794 \\
\text { (sq. H/13-d), PU548 }\end{array}$ & $6710 \pm 100$ & & $5801-5476$ & $\begin{array}{l}\text { Krajcar Bronić et al. 2010.495, } \\
\text { Fig. 3; Minichreiter, Botić } 2010 . \\
\text { 120, Fig. 14; Krajcar Bronić } 2011 . \\
\text { 182, 184, Fig. 4; Krajcar Bronić, } \\
\text { Minichreiter 2011.46, Fig. } 2\end{array}$ \\
\hline $\begin{array}{l}\text { Slavonski } \\
\text { Brod - } \\
\text { Galovo }\end{array}$ & Z-3922 & $\begin{array}{l}\text { charcoal at the } \\
\text { bottom of a working } \\
\text { pit } 291 \text { (sq. K/11-a) }\end{array}$ & $6709 \pm 82$ & & $5736-5486$ & $\begin{array}{l}\text { Krajcar Bronić et al. 2010.495, } \\
\text { Fig. 3; Minichreiter, Botić } 2010 . \\
\text { 120, Fig. 14; Krajcar Bronić } 2011 . \\
\text { 182, 184, Fig. 4; Krajcar Bronić, } \\
\text { Minichreiter 2011.46, Fig. } 2\end{array}$ \\
\hline $\begin{array}{l}\text { Slavonski } \\
\text { Brod - } \\
\text { Galovo }\end{array}$ & Z-3928 & $\begin{array}{l}\text { charcoal from pit- } \\
\text { dwelling } 153 \\
\text { (sq. E/13d) }\end{array}$ & $6700 \pm 86$ & & $5737-5482$ & $\begin{array}{l}\text { Krajcar Bronić et al. 2010.495, } \\
\text { Fig. 3; Minichreiter, Botić } 2010 . \\
\text { 120, Fig. 14; Krajcar Bronić } 2011 . \\
\text { 182, 184, Fig. 4; Krajcar Bronić, } \\
\text { Minichreiter 2011.46, Fig. } 2\end{array}$ \\
\hline $\begin{array}{l}\text { Slavonski } \\
\text { Brod - } \\
\text { Galovo }\end{array}$ & Z-3927 & $\begin{array}{l}\text { charcoal from pit- } \\
\text { dwelling } 108 \\
\text { (sq. G/11c) }\end{array}$ & $6659 \pm 61$ & & $5672-5483$ & $\begin{array}{l}\text { Krajcar Bronić et al. 2010.495, } \\
\text { Fig. 3; Minichreiter, Botić } 2010 . \\
\text { 120, Fig. 14; Krajcar Bronić } 2011 . \\
\text { 182, 184, Fig. 4; Krajcar Bronić, } \\
\text { Minichreiter 2011.46, Fig. } 2\end{array}$ \\
\hline $\begin{array}{l}\text { Slavonski } \\
\text { Brod - } \\
\text { Galovo } \\
\end{array}$ & Z-4879 & $\begin{array}{l}\text { burial pit 2243, } \\
\text { sq. } 1 / 6 \mathrm{~b}\end{array}$ & $6620 \pm 102$ & & $5720-5376$ & $\begin{array}{l}\text { Minichreiter } 2012.19-20 \text { (only } \\
\text { partial date published; } \\
\text { BP age first published here) }\end{array}$ \\
\hline $\begin{array}{l}\text { Slavonski } \\
\text { Brod - } \\
\text { Galovo }\end{array}$ & Z-4880 & $\begin{array}{l}\text { burial pit } 2243 \text {, } \\
\text { sq. } 1 / 6 \mathrm{~b}\end{array}$ & $6600 \pm 162$ & & $5896-5311$ & $\begin{array}{l}\text { Minichreiter } 2012.20 \text { (only } \\
\text { partial date published; } \\
\text { BP age first published here) }\end{array}$ \\
\hline
\end{tabular}

Tab. 1. continue 


\begin{tabular}{|c|c|c|c|c|c|c|}
\hline Site & Lab code & Material and context & $\begin{array}{l}{ }^{14} \text { C Age } \\
\text { (BP) }\end{array}$ & $\begin{array}{c}\delta^{13} \mathrm{C} / \\
{ }^{12} \mathrm{C}(\% \circ)\end{array}$ & $\begin{array}{c}\text { cal BC } \\
(2 \sigma)\end{array}$ & Reference \\
\hline $\begin{array}{l}\text { Slavonski } \\
\text { Brod - } \\
\text { Galovo }\end{array}$ & Z-3926 & $\begin{array}{l}\text { charcoal from hearth } \\
\text { near the kiln SU } 31 \text { in } \\
\text { burial pit } 9(\mathrm{sq} . \mathrm{C} / 4)\end{array}$ & $6567 \pm 66$ & & $5630-5380$ & $\begin{array}{l}\text { Krajcar Bronić et al. 2010.495, } \\
\text { Fig. 3; Minichreiter, Botić } 2010 . \\
\text { 120, Fig. 14; Krajcar Bronić } 2011 . \\
\text { 182, 184, Fig. 4; Krajcar Bronić, } \\
\text { Minichreiter 2011.46, Fig. } 2\end{array}$ \\
\hline $\begin{array}{l}\text { Slavonski } \\
\text { Brod - } \\
\text { Galovo }\end{array}$ & Z-3925 & $\begin{array}{l}\text { charcoal from a burial } \\
\text { pit } 9(\text { sq. B/3) }\end{array}$ & $6398 \pm 67$ & & $5483-5227$ & $\begin{array}{l}\text { Krajcar Bronić et al. 2010.495, } \\
\text { Fig. 3; Minichreiter, Botić } 2010 . \\
\text { 120, Fig. 14; Krajcar Bronić } 2011 . \\
\text { 182, 184, Fig. 4; Krajcar Bronić, } \\
\text { Minichreiter 2011.46, Fig. } 2\end{array}$ \\
\hline $\begin{array}{l}\text { Slavonski } \\
\text { Brod - } \\
\text { Galovo }\end{array}$ & Z-3583 & $\begin{array}{l}\text { charcoal from pit- } \\
\text { dwelling } 37 \\
\text { (sq. b/10-c) }\end{array}$ & $6300 \pm 80$ & & $5470-5061$ & $\begin{array}{l}\text { Minichreiter, Krajcar Bronić } \\
\text { 2006.12, Fig. 4; Minichreiter } \\
\text { 2007a.192, Fig. 1; Krajcar Bro- } \\
\text { nić, Minichreiter 2007.716; Mi- } \\
\text { nichreiter, Botić 2010.120, Fig. } \\
\text { 14; Krajcar Bronić 2011.182, 184, } \\
\text { Fig. 4; Krajcar Bronić, Minich- } \\
\text { reiter 2011.46, Fig. } 2\end{array}$ \\
\hline $\begin{array}{l}\text { Slavonski } \\
\text { Brod - } \\
\text { Galovo }\end{array}$ & Z-2935 & $\begin{array}{l}\text { charcoal from pit- } \\
\text { dwelling } 15 \text { (sq. D/2), } \\
\text { contains } 1 \text { skeletal } \\
\text { burial }\end{array}$ & $6185 \pm 130$ & & $5466-4803$ & $\begin{array}{l}\text { Obelić et al. 2002.616; Krajcar } \\
\text { Bronić et al. 2002.18; Minich- } \\
\text { reiter 2007a.192, Fig. 1; Krajcar } \\
\text { Bronić, Minichreiter 2007.716; } \\
\text { Minichreiter, Botić 2010.120, } \\
\text { Fig. 14; Krajcar Bronić 2011.182, } \\
\text { 184, Fig. 4; Krajcar Bronić, Mi- } \\
\text { nichreiter 2011.46, Fig. } 2\end{array}$ \\
\hline $\begin{array}{l}\text { Virovitica - } \\
\text { Brekinja }\end{array}$ & Beta 212603 & charcoal & $6470 \pm 70$ & & $5557-5312$ & Sekelj-Ivančan, Balen 2007.24 \\
\hline $\begin{array}{l}\text { Virovitica - } \\
\text { Brekinja }\end{array}$ & Beta 212601 & charcoal & $6350 \pm 80$ & & $5482-5079$ & Sekelj-Ivančan, Balen 2007.24 \\
\hline
\end{tabular}

Tab. 1. continue 
